\title{
Variations in milk protein fractions affect the efficiency of the cheese-making process
}

\author{
Claudio Cipolat-Gotet, ${ }^{*}$ Alessio Cecchinato, $\dagger^{1}$ Massimo Malacarne, ${ }^{*}$ Giovanni Bittante, $\dagger$ \\ and Andrea Summer* \\ *Department of Veterinary Science, University of Parma, Via del Taglio 10, I-43126 Parma, Italy \\ †Department of Agronomy, Food, Natural Resources, Animals and Environment (DAFNAE), University of Padova (Padua), viale dell'Università 16, \\ 35020 Legnaro (PD), Italy
}

\begin{abstract}
The aim of this study was to assess the influence of the amounts of the $\alpha_{\mathrm{S}^{-}}, \alpha_{\mathrm{S2}^{-}}, \beta$-, and $\kappa$-casein $(\mathrm{CN})$ and the $\alpha$-lactalbumin and $\beta$-lactoglobulin protein fractions on the efficiency of the cheese-making process independently of their genetic polymorphisms. The study was carried out on milk samples from 1,271 Brown Swiss cows from 85 herds classified into 4 categories according to management, feeding, and housing characteristics (traditional and modern systems). To assess the efficiency of the cheese-making process, we processed the milk samples according to a laboratory cheese-making procedure $(1,500 \mathrm{~mL} /$ sample $)$ and obtained the following measures: (1) 3 percentage cheese yields (\% $\mathrm{CY}_{\text {curd }}$, $\left.\% \mathrm{CY}_{\text {solids }}, \% \mathrm{CY}_{\text {water }}\right),(2) 2$ daily cheese yields obtained by multiplying \% CY (curd and total solids) by daily milk yields ( $\mathrm{dCY}_{\text {curd }}$, $\mathrm{dCY}$ solids $),(3) 4$ measures of nutrient recovery in the curd $\left(\mathrm{REC}_{\text {fat }}, \mathrm{REC}_{\text {protein }}, \mathrm{REC}_{\text {solids }}\right.$, $\mathrm{REC}_{\text {energy }}$ ), and (4) 2 measures of cheese-making efficiency in terms of the ratio between the observed and theoretical \%CY (Ef-\% $\mathrm{CY}_{\text {curd }}$, Ef-\% $\left.\mathrm{CY}_{\text {solids }}\right)$. All the aforementioned traits were analyzed by fitting 2 linear mixed models with protein fractions as fixed effects expressed as percentage in the milk (model M-\%milk) and as percentage of the total casein content (model M-\%cas) together with the effects of total casein content (only in model M-\%cas), daily milk yield (only in model M-\%milk; not for dCY traits), dairy system, herd (random effect), days in milk, parity, and vat. The efficiency of overall cheese yield $\left(\mathrm{Ef}-\% \mathrm{CY}_{\text {curd }}\right)$ was mostly positively associated with $\beta$-CN content in the milk, whereas $\mathrm{Ef}-\% \mathrm{CY}_{\text {solids }}$ was greater with higher amounts of $\kappa-\mathrm{CN}$ and $\alpha_{\mathrm{S}_{1}}-\mathrm{CN}$ (M-\% milk) due to the strong influence of both fractions on the recovery rate of milk components in the curd (fat and total solids, protein with $\alpha_{\mathrm{S} 1}-\mathrm{CN}$ only) when expressed as percentage of milk
\end{abstract}

Received January 26, 2018.

Accepted June 25, 2018.

${ }^{1}$ Corresponding author: alessio.cecchinato@unipd.it and of total casein; only $\beta-\mathrm{CN}$ was more important for $\mathrm{REC}_{\text {protein. }}$. In contrast, we found $\beta$-lactoglobulin to be highly negatively related to all the traits related to the cheese-making process and to the daily cheese yield per cow, whereas $\alpha$-lactalbumin was positively associated with the latter traits. Additional research on this topic is needed, with particular focus on the genetic and genomic aspects of the role of protein fractions in the cheese-making process and on the associations between genetic polymorphisms in milk protein and milk nutrient recovery in the curd.

Key words: milk protein, cheese-making, cheese yield, nutrient recovery

\section{INTRODUCTION}

The cheese production industry has a crucial need for an integrated approach to monitor all the relationships between milk quality and cheese-making so that it can guarantee a high level of efficiency (in terms of cheese yield and recovery of milk nutrients in the curd) across the entire process (Banks, 2007). Such an approach would also include gathering information on the milk quality of individual animals for use in current practices related to the genetic improvement of dairy cattle populations and for adjusting the milk-to-cheese economic value (i.e., milk payment systems).

Among the various factors involved, there is universal acknowledgment of the role played by the composition of protein fractions in the cheese-making process from milk gelation to cheese ripening (Emmons et al., 2003; Guinee, 2003; Caroli et al., 2009). As cheese consists of a paracasein reticulum in which fat globules and part of the soluble phase of milk are entrapped (Guinee, 2003; Rybak, 2014), the concentration of casein in milk is positively correlated with the quantity of cheese produced per unit of milk (percentage cheese yield). Moreover, physicochemical characteristics and structural properties of milk casein micelles (average size, proportion of caseins, concentration of colloidal calcium phosphate, casein genetic variants) influence the rheological prop- 
erties of the resulting rennet curd and, consequently, its capacity to retain milk constituents - mainly water, casein, and fat-in cheese (cheese-making efficiency; Bittante et al., 2012). In fact, when empirical predictive formulas for cheese yield using milk composition are to be developed, the coefficients of casein are higher than its own weight (Emmons et al., 1990).

Most studies at the cow level limit their analyses to the effect of protein fractions on the coagulation process (Macheboeuf et al., 1993; Hallén et al., 2007) or sample only a small number of animals (Wedholm et al., 2006; Hallén et al., 2010) due to the time-consuming and labor-intensive nature of cheese-making trials. Furthermore, there is a lack of knowledge about the role of proteins in milk nutrient recovery in the curd. Recently, we proposed a laboratory model cheese-manufacturing procedure that allows several cheese-making traits to be measured. This method was used to process more than 1,000 individual Brown Swiss milk samples, which revealed high variability in cheese-making traits related to dairy system (Bittante et al., 2015) and animal characteristics (Stocco et al., 2018). The aim of the present study was to examine the influence of the amounts of protein fractions (caseins and whey proteins), expressed as percentage in milk, and their proportions to total casein content on the efficiency of the cheesemaking process and on the daily cheese production of individual cows.

\section{MATERIALS AND METHODS}

\section{Animals, Dairy Systems, and Milk Sample Collection}

This study falls within the scope of the Cowability-Cowplus project. Herd selection, dairy farming systems, and sampling procedure are described in detail in Bittante et al. (2015). Briefly, milk samples were taken from a total of 1,264 Brown Swiss cows (3 subsamples per cow) during the evening milking. Cows were selected from the clinically healthy cows of 85 herds (a maximum of 15 cows per herd) located in Trento Province (Italy) to represent different parities and lactation stages. The herds were chosen from 610 farms and classified into 4 dairy farming systems (3 modern and 1 traditional).

One subsample of milk $(50 \mathrm{~mL})$ was transported to the Milk Quality Laboratory of the Trento Breeders Association (Trento, Italy) for milk composition analysis. The other subsamples were taken to the Milk Laboratory of the Department of Agronomy, Food, Natural Resources, Animals and Environment of the University of Padua (Legnaro, Padua, Italy) for cheesemaking and protein fraction analyses. All phases, from sampling to storage of milk samples, were standardized to maximize reproducibility among herds and collection dates. The Superbrown Consortium of Trento (Trento, Italy) provided information on the cows and herds.

\section{Milk Analyses and Processing}

Gross Composition Traits. Individual raw full-fat milk samples $(50 \mathrm{~mL})$ of all cows sampled were analyzed within $20 \mathrm{~h}$ of milking for gross composition (protein, casein, fat, lactose, and TS) using a MilkoScan FT6000 (Foss, Hillerød, Denmark) calibrated according to the following reference methods: fat (ISO, 2010b; ISO1211/IDF 1; gravimetric method, Röse-Gottlieb), protein (ISO, 2014; ISO 8968-1/IDF 20-1; titrimetric method, Kjeldahl), casein (ISO, 2004; ISO 17997-1/ IDF 29; titrimetric method, Kjeldahl), lactose (ISO, 2002; ISO 5765-1/IDF 79-1; enzymatic method), and TS (ISO, 2010a; ISO 6731/IDF 21; determination of TS content). Somatic cell count was measured with a Fossomatic FC counter (Foss) and log-transformed to SCS (Ali and Shook, 1980). Milk pH, adjusted for sample temperature, was obtained with a Crison Basic 25 electrode (Crison, Barcelona, Spain).

Milk Protein Fractions. Individual milk samples of all cows sampled (2 aliquots of $1 \mathrm{~mL}$ each per cow) were mixed with preservative (bronopol, 2-bromo2-nitropropan-1,3-diol, 0.6:100 vol/vol) to prevent microbial development and frozen at $-20^{\circ} \mathrm{C}$ in portable chilling devices immediately after collection and then stored at $-80^{\circ} \mathrm{C}$ until analysis. Frozen individual milk aliquots were prepared following the method proposed by Bobe et al. (1998). The contents of the casein $\left(\alpha_{\mathrm{S1}^{-}}\right.$, $\alpha_{\mathrm{S}^{-}}, \beta-$, and $\left.\kappa-\mathrm{CN}\right)$ and the whey protein $(\beta-\mathrm{LG}$ and $\alpha$-LA) fractions were assessed separately for each of their major genetic variants by the reversed-phase HPLC method (Bonfatti et al., 2008). The phosphorylated form of the $\alpha_{\mathrm{S} 1}-\mathrm{CN}$ (with 9 phosphorylated serine residues instead of 8) was also obtained (Bonfatti et al., 2011b). The genetic variants of each protein fraction ( $\mathrm{A}$ and $\mathrm{B}$ for $\kappa-\mathrm{CN}$; $\mathrm{A} 1, \mathrm{~A} 2$, and $\mathrm{B}$ for $\beta-\mathrm{CN}$; $\mathrm{A}$ and $\mathrm{B}$ for $\beta$-LG) were recorded for each milk sample, and their concentrations were summed to obtain the total concentration of the protein fraction.

Cheese-Making Efficiency. Individual raw fullfat milk samples $(2,000 \mathrm{~mL})$ were processed within 20 $\mathrm{h}$ of milking using the model cheese-making procedure $(1,500 \mathrm{~mL}$ of individual milk sample/vat) described by Stocco et al. (2018). Using this method, we were able to collect 7 traits related to the cheese-making process. The first 3 traits were measures of percentage cheese yield $(\mathbf{\%} \mathbf{C Y})$ representing the ratios between the weight of the milk processed and the weight of the curd, the curd DM, and the water retained in the curd (\% $\mathbf{C Y}_{\text {curd }}, \boldsymbol{\%} \mathbf{C Y}_{\text {solids }}$, and $\% \mathbf{C Y}_{\text {water }}$, respectively): 


$$
\begin{aligned}
& \%_{\mathrm{CY}} \text { curd, solids, water } \\
& \frac{\text { weight of curd, DM, or water in curd }(\mathrm{g})}{\text { weight of milk }(\mathrm{g})} \times 100 .
\end{aligned}
$$

The next 3 traits were milk component recoveries in the curd (REC) representing the ratios between the weight of the fat, protein, and DM in the curd and the weight of the corresponding component in the milk $(\mathbf{R E C}$ fat $\mathbf{R E C}_{\text {protein }}$, and $\mathbf{R E C} \mathbf{C}_{\text {solids }}$, respectively):

$$
\begin{aligned}
& \% \mathrm{REC}_{\text {fat, protein, solids }}= \\
& \frac{\text { weight of curd fat, protein, or DM }(\mathrm{g})}{\text { weight of milk fat, protein, or DM }(\mathrm{g})} \times 100 \text {. }
\end{aligned}
$$

We also estimated energy recovery in the curd (\%; NRC, 2001). The 2 cheese-making efficiency indicators $\left(\mathbf{E f}-\mathbf{\%} \mathbf{C} \mathbf{Y}_{\text {curd }}\right.$ and $\mathbf{E f - \%} \mathbf{C Y}$ solids $)$ were estimated as the ratio between the actual values of $\% \mathrm{CY}_{\text {curd }}$ and $\% \mathrm{CY}_{\text {solids, }}$, respectively, obtained in the laboratory from the model cheeses and the theoretical \%CY (Th\%CY $_{\text {curd }}$ and $\mathbf{T h}-\% \mathbf{C Y}$ solids; Supplemental Table S1; https://doi.org/10.3168/jds.2018-14503) calculated on the basis of milk composition using the predictive formulas proposed by Van Slyke and Price (1949):

$$
\begin{gathered}
\mathrm{Ef}-\% \mathrm{CY}_{\text {curd }}=\% \mathrm{CY}_{\text {curd }} / \mathrm{Th}-\% \mathrm{CY}_{\text {curd }} \\
\mathrm{Ef}-\% \mathrm{CY}_{\text {solids }}=\% \mathrm{CY}_{\text {solids }} / \mathrm{Th}-\% \mathrm{CY}_{\text {solids }} .
\end{gathered}
$$

The daily cheese yield traits $\left(\mathbf{d} \mathbf{C} \mathbf{Y}_{\text {curd }}\right.$ and $\mathbf{d} \mathbf{C Y} \mathbf{Y}_{\text {solids; }}$; $\mathrm{kg} / \mathrm{d}$ ) were calculated by multiplying the various $\% \mathrm{CY}$ (curd and TS, respectively) by the daily milk yield (dMY; kg/d).

\section{Statistical Analyses}

The quantitative effects of the milk protein fractions $\left(\alpha_{\mathrm{S1}^{-}}, \alpha_{\mathrm{S} 2^{-}}, \beta-\right.$, and $\kappa$-CN; $\beta-\mathrm{LG}$; and $\alpha$-LA), expressed as percentage in milk, on the cheese-making traits were analyzed using the MIXED procedure of SAS (SAS Institute Inc., Cary, NC) according to the following linear model (M-\%milk):

$$
\begin{aligned}
& \mathrm{y}_{i j k l m n o p q r s t u v w x y}=\mu+\text { dairy } \text { system }_{i} \\
& +\operatorname{herd}_{j}(\text { dairy system })_{i}+\operatorname{vat}_{k}+\mathrm{DIM}_{l}+\text { parity }_{m} \\
& +\mathrm{dMY}_{n}+\alpha_{\mathrm{S}^{-}} \mathrm{CN}_{o}+\alpha_{\mathrm{S}^{-}} \mathrm{CN} \mathrm{ph}_{p}+\alpha_{\mathrm{S}^{2}} \mathrm{CN}_{q}+\beta-\mathrm{CN}_{r} \\
& +\kappa-\mathrm{CN}_{s}+\beta-\mathrm{LG}_{t}+\alpha-\mathrm{LA}_{u}+\beta-\mathrm{CN}-\mathrm{GT}_{v}+\kappa-\mathrm{CN}-\mathrm{GT}_{w} \\
& +\beta-\mathrm{LG}-\mathrm{GT}_{x}+\mathrm{e}_{i j k l m n o p q r s t u v w x y},
\end{aligned}
$$

where $\mathrm{y}_{\text {ijklmnopqrstuwwxy }}$ is the observed trait (cheese-making traits: \%CY, REC, Th-\%CY, Ef-\%CY, and dCY); $\mu$ is

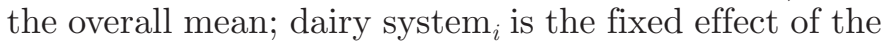
$i$ th class of dairy system ( $i=1$ to 4 ); $\operatorname{herd}_{j}$ (dairy system) ${ }_{i}$ is the random effect of the $j$ th herd within the $i$ th class of dairy system; vat ${ }_{k}$ is the fixed effect of the $k$ th vat ( $k=1$ to 15 classes); $\mathrm{DIM}_{l}$ is the fixed effect of the lth $60-d$ class of lactation ( $l=6$ classes); parity ${ }_{m}$ is the fixed effect of the $m$ th class of parity order $(m=1$ to $\geq 5$ ); $\mathrm{dMY}_{n}$ is the fixed effect of the $n$th class of dMY ( $\mathrm{n}=7$ classes; this effect was not included in the statistical model when dCY traits were analyzed); $\alpha_{\mathrm{S}_{1}-} \mathrm{CN}_{o}$ is the fixed effect of the oth class of $\alpha_{\mathrm{S}_{1}-\mathrm{CN}}$ content ( $o$ $=7$ classes $) ; \alpha_{S_{1}-} \mathrm{CN} \mathrm{ph}_{p}$ is the fixed effect of the $p$ th class of phosphorylated $\alpha_{\mathrm{S}^{1}} \mathrm{CN}$ content ( $p=7$ classes); $\alpha_{\mathrm{S}_{2}}-\mathrm{CN}_{q}$ is the fixed effect of the $q$ th class of $\alpha_{\mathrm{S}^{2}} \mathrm{CN}$ content ( $q=7$ classes); $\beta-\mathrm{CN}_{r}$ is the fixed effect of the $r$ th class of $\beta$-CN content ( $r=7$ classes); $\kappa-\mathrm{CN}_{s}$ is the fixed effect of the sth class of $\kappa$-CN content $(s=7$ classes); $\beta-\mathrm{LG}_{t}$ is the fixed effect of the th class of $\beta$-LG content ( $t=7$ classes); $\alpha-\mathrm{LA}_{u}$ is the fixed effect of the $u$ th class of $\alpha$-LA content ( $u=7$ classes); and $\mathrm{e}_{i j k l m n o p q r s t u w w x}$ is the residual random error $\sim N\left(0, \sigma_{e}^{2}\right)$. Herd and residuals were assumed to be normally distributed with a mean of zero and variances of $\sigma_{h}^{2}$ and $\sigma_{e}^{2}$, , respectively. Although the effect of genetic variants is beyond the scope of this study, the protein genotypes $(\mathrm{GT})$ of each fraction $(\beta-\mathrm{CN}, \kappa-\mathrm{CN}$, and $\beta-\mathrm{LG})$ were included in the model to account for potential specific effects of the genetic variants and to avoid possible confusion with the quantitative effect of the protein fraction concentration. We neither report nor discuss the effect of genetic variants.

A second, qualitative model (M-\%Cas) was used to study the effects of milk protein fractions expressed as proportions of total casein. In this model, the effect of the total casein content of milk (7 classes) replaced the effect of dMY as the fixed effect to distinguish between the quantitative effect of total casein and the qualitative effect of its composition. As casein is directly involved in the cheese-making process, we decided to express all the protein fractions as percentage of total casein instead of total milk protein, thereby treating the whey protein fractions as supplemental material rather than constituents of cheese, and avoided negative multicollinearity between caseins and whey proteins.

Each of the 7 classes of protein fractions (as for total casein content and dMY) was determined on the basis of the distribution of the variables. Each individual class explained 0.5 SD of the variable; the fourth was centered on the mean value, and the first and seventh represented the tails of the distribution. Polynomial contrasts $(P<0.05)$ were obtained to evaluate the 
Table 1. Descriptive statistics of milk yield, protein fraction ( $\%$ in milk and $\%$ on casein), cheese-making traits, and daily cheese production ${ }^{1}$

\begin{tabular}{|c|c|c|c|c|}
\hline Trait & Mean & $\mathrm{SD}$ & $\mathrm{P} 5$ & P95 \\
\hline Daily milk yield, kg/d & 24.4 & 7.9 & 12.3 & 37.9 \\
\hline Fat, $\%$ & 4.22 & 0.73 & 3.14 & 5.42 \\
\hline Protein, \% & 3.71 & 0.44 & 3.03 & 4.43 \\
\hline Casein, \% & 2.89 & 0.33 & 2.38 & 3.44 \\
\hline Casein index, \% & 0.78 & 0.01 & 0.76 & 0.80 \\
\hline Lactose, $\%$ & 4.85 & 0.20 & 4.50 & 5.13 \\
\hline SCS, unit & 2.98 & 1.86 & 0.21 & 6.20 \\
\hline \multicolumn{5}{|l|}{ Milk protein fraction, $\%$} \\
\hline \multicolumn{5}{|l|}{ In milk } \\
\hline$\alpha_{\mathrm{S} 1}-\mathrm{CN}$ & 0.95 & 0.13 & 0.76 & 1.18 \\
\hline$\alpha_{\mathrm{S} 1}-\mathrm{CN}_{-} \mathrm{Ph}^{2}$ & 0.05 & 0.02 & 0.02 & 0.10 \\
\hline$\alpha_{S_{2}-} \mathrm{CN}$ & 0.34 & 0.06 & 0.25 & 0.44 \\
\hline$\beta-\mathrm{CN}$ & 1.19 & 0.15 & 0.95 & 1.44 \\
\hline$\kappa-\mathrm{CN}$ & 0.35 & 0.07 & 0.23 & 0.46 \\
\hline$\beta-\mathrm{LG}$ & 0.33 & 0.07 & 0.22 & 0.45 \\
\hline$\alpha-\overline{L A}$ & 0.09 & 0.02 & 0.06 & 0.12 \\
\hline \multicolumn{5}{|l|}{ On casein } \\
\hline$\alpha_{\mathrm{S} 1}-\mathrm{CN}$ & 33.0 & 2.1 & 29.6 & 36.7 \\
\hline$\alpha_{\mathrm{S} 1}-\mathrm{CN}-\mathrm{Ph}^{2}$ & 1.86 & 0.79 & 0.60 & 3.26 \\
\hline$\alpha_{\mathrm{S}^{2}} \mathrm{CN}$ & 11.8 & 1.5 & 9.7 & 14.4 \\
\hline$\beta-\mathrm{CN}$ & 41.2 & 3.0 & 37.0 & 46.7 \\
\hline$\kappa-\mathrm{CN}$ & 12.2 & 1.8 & 8.8 & 14.6 \\
\hline$\beta-L G$ & 11.2 & 2.0 & 8.2 & 14.5 \\
\hline$\alpha-\mathrm{LA}$ & 3.02 & 0.65 & 1.95 & 4.09 \\
\hline \multicolumn{5}{|l|}{ Cheese yield (CY), \% } \\
\hline$\% \mathrm{CY}_{\text {curd }}$ & 15.0 & 1.89 & 12.0 & 18.3 \\
\hline$\% \mathrm{CY}_{\text {solids }}$ & 7.22 & 0.93 & 5.77 & 8.80 \\
\hline$\% \mathrm{CY}_{\text {water }}$ & 7.80 & 1.28 & 5.85 & 9.95 \\
\hline \multicolumn{5}{|c|}{ Theoretical \%CY (Th-\%CY) } \\
\hline Th- $\% \mathrm{CY}_{\text {curd }}$ & 15.2 & 1.8 & 12.3 & 18.4 \\
\hline Th- $\% \mathrm{CY}_{\text {solids }}$ & 7.30 & 0.88 & 5.89 & 8.85 \\
\hline \multicolumn{5}{|c|}{ Efficiency of \%CY (Ef-\%CY) } \\
\hline Ef- $\% \mathrm{CY}_{\text {curd }}$ & 0.99 & 0.09 & 0.85 & 1.14 \\
\hline Ef-\%CY & 0.99 & 0.06 & 0.90 & 1.07 \\
\hline \multicolumn{5}{|c|}{ Nutrient recovery (REC), \% } \\
\hline $\mathrm{REC}_{\text {protein }}$ & 78.1 & 2.41 & 74.0 & 81.9 \\
\hline $\mathrm{REC}_{\text {fat }}$ & 89.9 & 3.58 & 82.6 & 94.5 \\
\hline $\mathrm{REC}_{\text {solids }}$ & 52.0 & 3.58 & 46.1 & 58.1 \\
\hline $\mathrm{REC}_{\text {energy }}$ & 67.3 & 3.32 & 61.8 & 72.5 \\
\hline \multicolumn{5}{|c|}{ Daily cheese production $(\mathrm{dCY}), \mathrm{kg} / \mathrm{d}$} \\
\hline $\mathrm{dCY}_{\text {curd }}$ & 3.63 & 1.17 & 1.80 & 5.73 \\
\hline $\mathrm{dCY}_{\text {solids }}$ & 1.74 & 0.57 & 0.87 & 2.72 \\
\hline $\mathrm{dCY}_{\text {water }}$ & 1.88 & 0.63 & 0.92 & 3.04 \\
\hline
\end{tabular}

${ }^{1} \mathrm{P} 5=5$ th percentile; $\mathrm{P} 95=95$ th percentile.

${ }^{2}$ The $\alpha_{\mathrm{S1}} \mathrm{CN}$ fraction with 9 instead of 8 phosphorylated serine residues.

trends (linear, quadratic, and cubic relationships) of cheese-making traits for each protein fraction effect.

\section{RESULTS}

\section{Descriptive Statistics}

Descriptive statistics of milk gross composition, protein fractions [expressed as \% (wt/wt) of milk and as $\%$ of total casein content], and cheese-making traits are presented in Table 1. Most of these traits were almost normally distributed, showing kurtosis and skewness values close to zero, with the exception of fat, fat re- covery in the curd, lactose, and $\alpha_{\mathrm{S} 2}-\mathrm{CN}$ (\% of casein), which exhibited a tendency to a leptokurtic distribution (data not shown). Individual cows produced an average of $24.4 \mathrm{~kg}$ of milk/d with a composition of $4.22 \%$ fat, $3.71 \%$ protein, and $4.85 \%$ lactose. Casein content was $2.89 \%$ and had a ratio to protein of 0.78 (casein number), whereas the ratio to fat had a mean value of 0.68 .

As expected, the predominant casein fraction was $\beta-\mathrm{CN}$, which, together with $\alpha_{\mathrm{S} 1}-\mathrm{CN}$, represented about three-quarters of total casein content. The remainder was shared by $\alpha_{S_{2}}-\mathrm{CN}$ and $\kappa-\mathrm{CN}$, with a small presence of $\alpha_{S_{1}-} \mathrm{CN}$-phosphorylated form $(\mathbf{P h})$. Analysis of the whey protein fractions revealed there to be approxi- 
mately 3 times the amount of $\beta$-LG as $\alpha-\mathrm{LA}$, although the variability of these 2 fractions was similar when expressed as coefficient of variation $(\mathbf{C V})$. The variability (in SD) of each protein was positively correlated with their quantities also in the case of caseins.

The mean value of $\% \mathrm{CY}_{\text {curd }}$ was $15.0 \%$ and was almost equally distributed between TS and water in the curd $\left(\% \mathrm{CY}_{\text {solids }}=7.22 \% ; \% \mathrm{CY}_{\text {water }}=7.80 \%\right)$. The observed trait was slightly lower than the $\mathrm{Th}-\% \mathrm{CY}_{\text {curd }}$, resulting in an Ef-\% $\mathrm{CY}_{\text {curd }}$ equal to 0.99. The average composition of fresh curd was $19.5 \%$ protein, $26.2 \%$ fat, and $48.4 \%$ TS (data not shown), resulting from average recoveries in the curd of $78.1 \%$ for protein, $89.9 \%$ for fat, and $52.0 \%$ for TS. Protein recovery in the curd had a lower standard deviation than the other REC, but the CV value was higher than the casein index (2.4\% for $\mathrm{REC}_{\text {protein }}$ vs. $1.6 \%$ for the casein index) with respect to both casein losses in the whey and retention of whey proteins in the curd.

Daily cheese production of individual cows was on average $3.63 \mathrm{~kg} / \mathrm{d}$ for $\mathrm{dCY}_{\text {curd }}$ and 1.74 for $\mathrm{dCY}_{\text {solids. }}$. These traits had a higher CV (about 33\%) than \% CY in direct relation to the high variability in daily milk production.

\section{Cheese-Making}

Tables 2, 3, and 4 and Supplemental Table S2 (https: //doi.org/10.3168/jds.2018-14503) show the results of the ANOVA (M-\%milk and M-\%cas) for the \%CY, REC, Ef-\%CY, and dCY groups of traits, respectively, and of the contrasts (linear, quadratic, and cubic) for total casein content and each protein fraction. The effects related to individual cows (DIM and order of parity), farm (individual herd and dairy system), and cheese-making vat were included in both the M-\%milk and M-\%cas models to correct the cheese-making traits for these sources of variation. However, we did not observe any relevant significant differences between the 2 models (Tables 2, 3, and 4 and Supplemental Table S2; https://doi.org/10.3168/jds.2018-14503). Effects of protein genotypes $(\beta-\mathrm{CN}, \kappa-\mathrm{CN}$, and $\beta-\mathrm{LG})$ were also included in the models so that we could analyze the effects of the amounts of individual protein fractions in milk and their proportions in casein independently of their potential genetic variants.

Moving on to total casein content (model M-\%cas), the increment in this component had a favorable effect on both $\mathrm{Ef}-\% \mathrm{CY}_{\text {curd }}$ and $\mathrm{Ef}-\% \mathrm{CY}_{\text {solids }}$ due to its linear positive relationship with \% CY and REC traits (Figure $1)$. As expected, the effects of each fraction expressed as percentage in milk were more relevant for all the \% CY traits than the effects observed in M-\%cas, as the former traits are closely related to total protein quantity in each processed milk sample. In all the REC traits, the proportions of protein fractions to total casein (model M-\%cas) were more important than those in $\% \mathrm{CY}$, although the amounts of proteins in milk were also found to have a greater influence on REC traits (M-\%milk).

Among casein fractions, we found $\alpha_{\mathrm{S}^{-}} \mathrm{CN}$ to be very important for the $3 \% \mathrm{CY}$ traits when considered as percentage of milk (M-\%milk; Figure 2a). This protein, together with $\beta$-CN the most important quantitatively (Table 1), produced a linear increase in the 3 cheese yields, with $\% \mathrm{CY}_{\text {curd }}$ increasing by 3.0 percentage points ( $20 \%$ of the average value) from the first to the last class of $\alpha_{\mathrm{S}_{1}}-\mathrm{CN}$ least squares means. Although the recoveries of individual and overall components [Figure 3a and Supplemental Figure S1a (https://doi.org/10 $.3168 / j d s .2018-14503)$, respectively] were also linearly influenced by the increase in this casein fraction in milk, $\alpha_{S_{1}}$ CN increased cheese-making efficiency only with respect to Ef-\% $\mathrm{CY}_{\text {solids }}$ (M-\%milk; Table 3; Figure 4a). The effect of its phosphorylated form was positive but not very important (Figures $2 \mathrm{~b}, 3 \mathrm{~b}, 4 \mathrm{~b}$, and $5 \mathrm{~b}$ ). Moreover, the amount of $\alpha_{\mathrm{S}^{-}} \mathrm{CN}-\mathrm{Ph}$ in total casein content reduced milk protein recovery in the curd (Figure $3 b)$.

Unlike $\alpha_{\mathrm{S}_{1}} \mathrm{CN}$, the effect of the $\alpha_{\mathrm{S} 2} \mathrm{CN}$ fraction was mostly significant when expressed as percentage of total casein and lowered cheese-making efficiency in terms of solids yield (Ef-\%CY $\mathrm{Colids}_{\text {; }}$ Figure 4c). The effect of $\alpha_{\mathrm{S}^{2}} \mathrm{CN}$ on all \% CY traits was linearly negative in the M-\%cas model, whereas a quadratic pattern for $\% \mathrm{CY}_{\text {curd }}, \% \mathrm{CY}_{\text {solids }}$, and $\mathrm{REC}_{\text {solids }}$ was found in the $\mathrm{M}-$ $\%$ milk model. The $\mathrm{REC}_{\text {protein }}$ and energy recovery in the curd were also negatively influenced by the increase in the content of this protein fraction in milk and in casein [Figure 2c and Supplemental Figure S1c (https://doi .org/10.3168/jds.2018-14503), respectively].

When expressed as percentage in milk, $\beta-\mathrm{CN}$ was the protein fraction with the greatest effect on $\% \mathrm{CY}_{\text {curd }}$ (Figure 2d) and had strong positive importance for all 3 observed \%CY traits, causing, in particular, an increase in water retention in the curd (Figure 2d). Although $\beta-\mathrm{CN}$ had a negative influence on $\mathrm{REC}_{\mathrm{fat}}$ (Figure 3d), the strong effect of this protein fraction on all the $\% \mathrm{CY}$ traits was due to its positive relationship with $\mathrm{REC}_{\text {protein }}$ and $\mathrm{REC}_{\text {solids }}$ [Figure 3d and Supplemental Figure S1d (https://doi.org/10.3168/jds.2018 -14503), respectively]. In qualitative terms, we did not find any strong relationships between $\beta-\mathrm{CN}$ and the observed cheese-making traits in the M-\%cas model, although this fraction influenced the efficiency of \%CY with significant quadratic (with intermediate optimum value) and cubic (decreasing) contrasts for $\mathrm{Ef}-\% \mathrm{CY}_{\text {curd }}$ and Ef-\%CY $\mathrm{Colids}_{\text {, }}$ respectively (Figure 4d). 
Table 2. Analysis of variance (model M- $\%$ milk and model M- $\%$ cas $^{1} ; F$-value and significance) for cheese yield (\%CY; curd, solids, and retained water) and results of contrasts (linear, quadratic, and cubic; $F$-value and significance) for total casein content and milk protein fractions

\begin{tabular}{|c|c|c|c|c|c|c|}
\hline \multirow[b]{2}{*}{ Effect } & \multicolumn{2}{|c|}{$\% \mathrm{CY}_{\text {curd }}$} & \multicolumn{2}{|c|}{$\% \mathrm{CY}_{\text {solids }}$} & \multicolumn{2}{|c|}{$\% \mathrm{CY}_{\text {water }}$} \\
\hline & M-\%milk & M-\%cas & M-\%milk & M-\%cas & M-\%milk & M-\%cas \\
\hline Herd $^{2}$ & 35 & 34 & 19 & 19 & 47 & 45 \\
\hline Vat & $1.9^{*}$ & 1.6 & $2.5^{* *}$ & $2.2^{* *}$ & $1.7^{*}$ & $1.7^{*}$ \\
\hline DIM, d & $2.3^{*}$ & 1.9 & 0.6 & 0.4 & $3.5^{* *}$ & $2.9^{*}$ \\
\hline Parity & 1.7 & 1.5 & 2.3 & 2.2 & $3.2^{*}$ & 1.7 \\
\hline$\kappa-\mathrm{CN}$ & 1.6 & 1.5 & 0.3 & 0.4 & $3.6^{*}$ & 2.4 \\
\hline$\beta-L G$ & $10.7^{* * *}$ & $6.7^{* *}$ & 2.4 & 1.0 & $6.8^{* *}$ & $4.6^{*}$ \\
\hline Daily milk yield, $\mathrm{kg} / \mathrm{d}$ & 0.9 & - & 0.4 & - & 1.4 & - \\
\hline \multicolumn{7}{|l|}{ 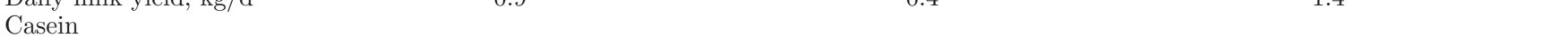 } \\
\hline Linear & - & $791.7^{* * *}$ & - & $441.2^{* * *}$ & - & $410.6^{* * *}$ \\
\hline Quadratic & - & 0.4 & - & $9.0^{* *}$ & - & 2.3 \\
\hline Cubic & \multicolumn{5}{|c|}{$\alpha_{S_{1}-} \mathrm{CN}$} & 2.7 \\
\hline Linear & $33.7^{* * *}$ & 3.8 & $18.8^{* * *}$ & 2.7 & $16.5^{* * *}$ & 0.5 \\
\hline Quadratic & 1.6 & 3.1 & 0.1 & 0.7 & 3.1 & 2.5 \\
\hline Cubic & 0.8 & 0.2 & 1.9 & 0.6 & 0.0 & 0.6 \\
\hline \multicolumn{7}{|l|}{$\alpha_{\mathrm{S}-\mathrm{CN}}$} \\
\hline Linear & 0.6 & $16.0^{* * *}$ & 2.7 & $13.1^{* * *}$ & 0.4 & $10.6^{* *}$ \\
\hline Quadratic & $5.2^{*}$ & 3.2 & $9.1^{* *}$ & $5.9^{*}$ & 0.0 & 0.1 \\
\hline Cubic & 0.4 & $4.8^{*}$ & 0.2 & 1.7 & 0.5 & $5.2^{*}$ \\
\hline \multicolumn{7}{|l|}{$\beta-\mathrm{CN}$} \\
\hline Linear & $124.6^{* * *}$ & 0.3 & $29.1^{* * *}$ & 0.9 & $98.8^{* * *}$ & 0.0 \\
\hline Quadratic & 1.4 & 0.0 & 3.2 & 1.9 & 0.0 & $3.9^{*}$ \\
\hline Cubic & 0.5 & 1.4 & 0.0 & 0.2 & 2.0 & 0.1 \\
\hline \multicolumn{7}{|l|}{$\kappa-\mathrm{CN}$} \\
\hline Linear & $34.2^{* * *}$ & 0.0 & $34.8^{* * *}$ & 2.2 & $16.0^{* * *}$ & 1.4 \\
\hline \multicolumn{7}{|l|}{$\alpha-\mathrm{LA}$} \\
\hline Root mean squared error & 0.98 & 1.01 & 0.61 & 0.61 & 0.72 & 0.74 \\
\hline
\end{tabular}

${ }^{1}$ Proteins expressed as content in milk (M-\%milk) or as percentage of total casein content (M-\%cas).

${ }^{2}$ The variance of herd within dairy system is expressed as ratio with total variance (herd plus residual).

${ }^{3}$ The $\alpha_{\mathrm{S} 1}$ CN fraction with 9 instead of 8 phosphorylated serine residues.

${ }^{*} P<0.05 ;{ }^{* *} P<0.01 ;{ }^{* * *} P<0.001$.

The $\kappa$-CN fraction expressed as percentage in milk was important for all the \% CY traits, exhibiting linear and positive relationships (Figure 2e); this and $\alpha_{S 1}-\mathrm{CN}$ were the only fractions positively influencing Ef-\% $\mathrm{CY}_{\text {solids }}$. The results explaining the relationship between curd recoveries and the $\kappa-\mathrm{CN}$ fraction were more heterogeneous. Although this protein fraction had a very clear and favorable influence on the recovery of fat in the curd in both the M-\%milk and the M-\%cas models, it negatively influenced $\mathrm{REC}_{\text {protein }}$, especially when expressed as percentage of total casein (Figure $3 \mathrm{e})$.

$\beta$-Lactoglobulin had a strong negative influence on all the cheese-making traits in both the M-\%milk and $\mathrm{M}-\%$ cas models, particularly for Ef- $\% \mathrm{CY}_{\text {curd }}$ and Ef$\% \mathrm{CY}_{\text {solids }}$ (Figure 4f). Contrary to what we observed for $\beta-\mathrm{LG}, \alpha-\mathrm{LA}$ was the protein fraction with the least influence on the \%CY in both statistical models. Despite the significance of the effect of $\alpha-\mathrm{LA}$ on $\% \mathrm{CY}_{\text {curd }}$ and $\mathrm{CY}_{\text {water }}$ in the M-\%milk model, the variability of these 
Table 3. Analysis of variance (model M- $\%$ milk and model M- $\%$ cas $^{1} ; F$-value and significance) for milk protein and fat recovery (REC) in the curd and for efficiency of cheese yield (Ef-\%CY), together with results of contrasts (linear, quadratic, and cubic; $F$-value and significance) for total casein content and milk protein fractions

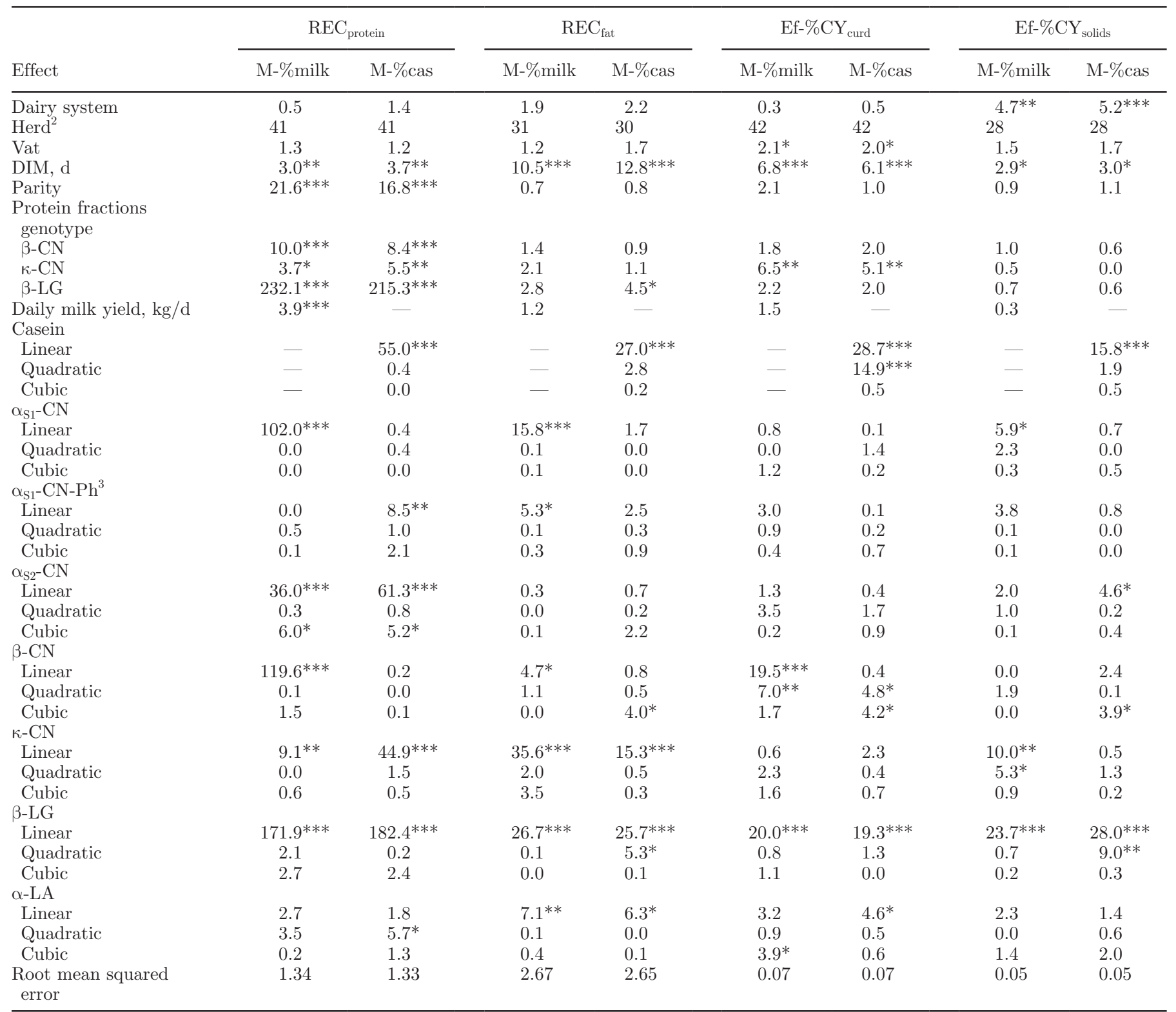

${ }^{1}$ Proteins expressed as content in milk (M-\%milk) or as percentage of total casein content (M-\%cas).

${ }^{2}$ The variance of herd within dairy system and season is expressed as ratio with total variance (herd plus residual).

${ }^{3}$ The $\alpha_{\mathrm{S}^{-}} \mathrm{CN}$ fraction with 9 instead of 8 phosphorylated serine residues.

${ }^{*} P<0.05 ;{ }^{* *} P<0.01$; *** $P<0.001$.

traits in relation to this effect was mostly negligible. Moreover, the only notable effect of $\alpha$-LA was that it had a favorable effect on $\mathrm{REC}_{\mathrm{fat}}$, whether expressed as percentage in milk or in relation to total casein (Figures $3 g$ ).

When individual dCY traits were assessed, we found $\alpha_{\mathrm{S1}}$-CN to have positive effects and $\alpha_{S_{2}}-\mathrm{CN}$ to have negative effects (Figure 5a and c), results that reflect, in part, what we observed for \%CY. $\beta$-Lactoglobulin also had a negative effect, whereas $\alpha$-LA, although of negligible importance for all the \%CY traits, had a positive linear effect on $\mathrm{dCY}$ traits, whether expressed as percentage in milk or with respect to casein (Figure $5 \mathrm{~g})$. 


\section{DISCUSSION}

\section{Effect of Total Casein Content}

Researchers who have studied the relationship between casein or protein (or their fractions) and cheese yields at the individual cow level (Marziali and $\mathrm{Ng}$ Kwai-Hang, 1986; Wedholm et al., 2006) have not attended to the effects of proteins on the efficiency of cheese production and individual milk component recoveries in the curd. Furthermore, results are affected by laboratory conditions and procedures that do not always simulate the cheese-making process in field conditions - for example, the use of a centrifuge to separate the curd from the whey (Hallén et al., 2010). It is widely recognized that the effects of casein on cheese-making can be influenced by processing conditions and by the category of cheese being produced. The microstructure of the coagulum, and afterward the structure of the formed curd, markedly affect rheological and syneretic

Table 4. Analysis of variance (model M-\%milk and model M- $\%$ cas $^{1} ; F$-value and significance) for daily cheese production (dCY) and results of contrasts (linear, quadratic, and cubic; F-value and significance) for total casein content and milk protein fractions

\begin{tabular}{|c|c|c|c|c|}
\hline \multirow[b]{2}{*}{ Effect } & \multicolumn{2}{|c|}{$\mathrm{dCY}_{\text {curd }}$} & \multicolumn{2}{|c|}{$\mathrm{dCY}_{\text {solids }}$} \\
\hline & M-\%milk & M-\%cas & M-\%milk & M-\%cas \\
\hline Dairy system & $16.2^{* * *}$ & $16.1^{* * *}$ & $19.7^{* * *}$ & $18.8^{* * *}$ \\
\hline Herd $^{2}$ & 39 & 40 & 35 & 37 \\
\hline Vat & 1.2 & 1.2 & 1.4 & 1.6 \\
\hline DIM, d & $22.8^{* * *}$ & $20.2^{* * *}$ & $18.4^{* * *}$ & $17.4^{* * *}$ \\
\hline Parity & $19.4^{* * *}$ & $21.2^{* * *}$ & $23.5^{* * *}$ & $25.4^{* * *}$ \\
\hline \multicolumn{5}{|l|}{ Protein fractions genotype } \\
\hline$\beta-\mathrm{CN}$ & 1.9 & $3.3^{*}$ & 0.6 & 1.7 \\
\hline$\kappa-\mathrm{CN}$ & 1.2 & 0.8 & 0.7 & 0.4 \\
\hline$\beta-\mathrm{LG}$ & 1.8 & 1.4 & 1.4 & 0.8 \\
\hline \multicolumn{5}{|l|}{ Casein } \\
\hline Linear & - & $4.5^{*}$ & - & 1.1 \\
\hline Quadratic & - & $4.9^{*}$ & - & 1.5 \\
\hline Cubic & - & 0.5 & - & 0.0 \\
\hline \multicolumn{5}{|l|}{$\alpha_{\mathrm{S} 1^{-}} \mathrm{CN}$} \\
\hline Linear & $21.8^{* * *}$ & $6.5^{*}$ & $23.9^{* * *}$ & $7.2^{* *}$ \\
\hline Quadratic & 0.2 & $4.8^{*}$ & 0.0 & $4.2^{*}$ \\
\hline Cubic & 0.0 & 0.1 & 0.2 & 0.0 \\
\hline \multicolumn{5}{|l|}{$\alpha_{\mathrm{S}^{-}} \mathrm{CN}-\mathrm{Ph}^{3}$} \\
\hline Linear & $4.1^{*}$ & 2.2 & 2.6 & 1.9 \\
\hline Quadratic & 0.7 & 0.8 & 0.0 & 0.3 \\
\hline Cubic & 0.1 & 1.1 & 0.0 & 1.8 \\
\hline \multicolumn{5}{|l|}{$\alpha_{\mathrm{S} 2^{-}} \mathrm{CN}$} \\
\hline Linear & $24.3^{* * *}$ & $9.0^{* *}$ & $26.1^{* * *}$ & $8.9^{* *}$ \\
\hline Quadratic & 1.5 & 0.1 & 0.2 & 0.0 \\
\hline Cubic & 0.9 & 1.3 & 0.9 & 0.6 \\
\hline \multicolumn{5}{|l|}{$\beta-\mathrm{CN}$} \\
\hline Linear & 0.0 & 2.3 & 2.0 & 1.5 \\
\hline Quadratic & 3.0 & 0.5 & 1.3 & 0.0 \\
\hline Cubic & 0.0 & 0.0 & 0.8 & 0.1 \\
\hline \multicolumn{5}{|l|}{$\kappa-\mathrm{CN}$} \\
\hline Linear & 0.0 & 1.1 & 0.2 & 2.5 \\
\hline Quadratic & 1.2 & 0.1 & 2.2 & 0.6 \\
\hline Cubic & 2.7 & 0.5 & 2.0 & 0.6 \\
\hline \multicolumn{5}{|l|}{$\beta-\mathrm{LG}$} \\
\hline Linear & $19.1^{* * *}$ & $20.2^{* * *}$ & $13.9^{* * *}$ & $13.7^{* * *}$ \\
\hline Quadratic & 0.2 & 0.1 & 0.1 & 0.0 \\
\hline Cubic & 2.1 & 0.0 & 1.5 & 0.3 \\
\hline \multicolumn{5}{|l|}{$\alpha-\mathrm{LA}$} \\
\hline Linear & $15.0^{* * *}$ & $22.8^{* * *}$ & $12.9^{* * *}$ & $22.1^{* * *}$ \\
\hline Quadratic & 1.1 & 0.8 & 1.9 & 0.7 \\
\hline Cubic & 0.2 & 0.1 & 0.0 & 0.7 \\
\hline Root mean squared error & 0.72 & 0.72 & 0.36 & 0.36 \\
\hline
\end{tabular}

${ }^{1}$ Proteins expressed as content in milk (M-\%milk) or as percentage of total casein content (M-\%cas).

${ }^{2}$ The variance of herd within dairy system and season is expressed as ratio with total variance (herd plus residual).

${ }^{3}$ The $\alpha_{\mathrm{S} 1}-\mathrm{CN}$ fraction with 9 instead of 8 phosphorylated serine residues.

${ }^{*} P<0.05 ;{ }^{* *} P<0.01 ;{ }^{* * *} P<0.001$. 
properties, and subsequently the $\% \mathrm{CY}_{\text {curd }}$, due to the different recoveries of milk components (protein and fat) in the curd (Guinee et al., 1995) and the amount of water retained. In the present study, we examined the pattern of \%CY, REC, Ef-\%CY, and dCY traits in relation to total casein content and all the protein fractions expressed as percentage in milk and as percentage of total casein. As expected, casein and its fractions
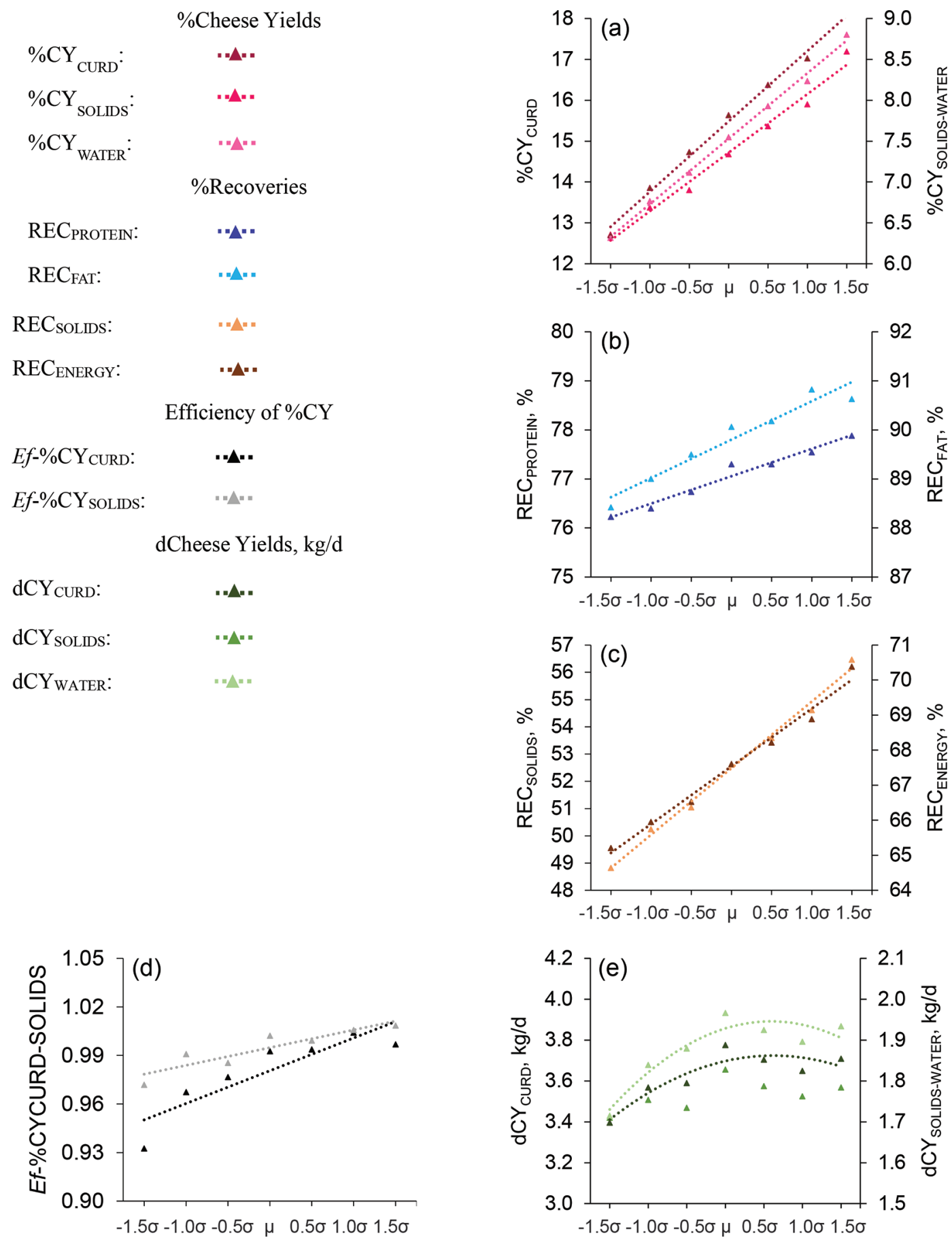

Figure 1. Effect of casein content on (a) cheese yields (\%CY; $\% \mathrm{CY}_{\text {curd }}, \% \mathrm{CY}_{\text {solids }}$, and $\left.\% \mathrm{CY}_{\text {water }}\right)$, (b) milk components recovery (REC) in the curd $\left(\mathrm{REC}_{\text {protein }}\right.$ and $\left.\mathrm{REC}_{\mathrm{fat}}\right)$, (c) milk REC in the curd $\left(\mathrm{REC}_{\text {solids }}\right.$ and $\mathrm{REC}_{\text {energy }}$ ), (d) efficiency of cheese yield (Ef-\%CY; Ef-\%CY curd and $\left.\mathrm{Ef}-\% \mathrm{CY}_{\text {solids }}\right)$, and (e) daily cheese yields $\left(\mathrm{dCY} ; \mathrm{dCY}_{\text {curd }}, \mathrm{dCY}_{\text {solids }}\right.$, and $\mathrm{dCY}$ water $)$. Results of the polynomial contrasts have been reported as the response curve (linear, quadratic, or cubic) of the variables across classes of milk casein. For each protein fraction, the class 4 represents the central class $(-0.25$ to $+0.25 \mathrm{SD}$ with respect to the mean). The amplitude of the other classes is $0.5 \mathrm{SD}$. Color version available online. 
(expressed as \% of milk) had a positive linear effect on almost all the observed \%CY traits, and we found that an increment in milk casein of 0.1 percentage points
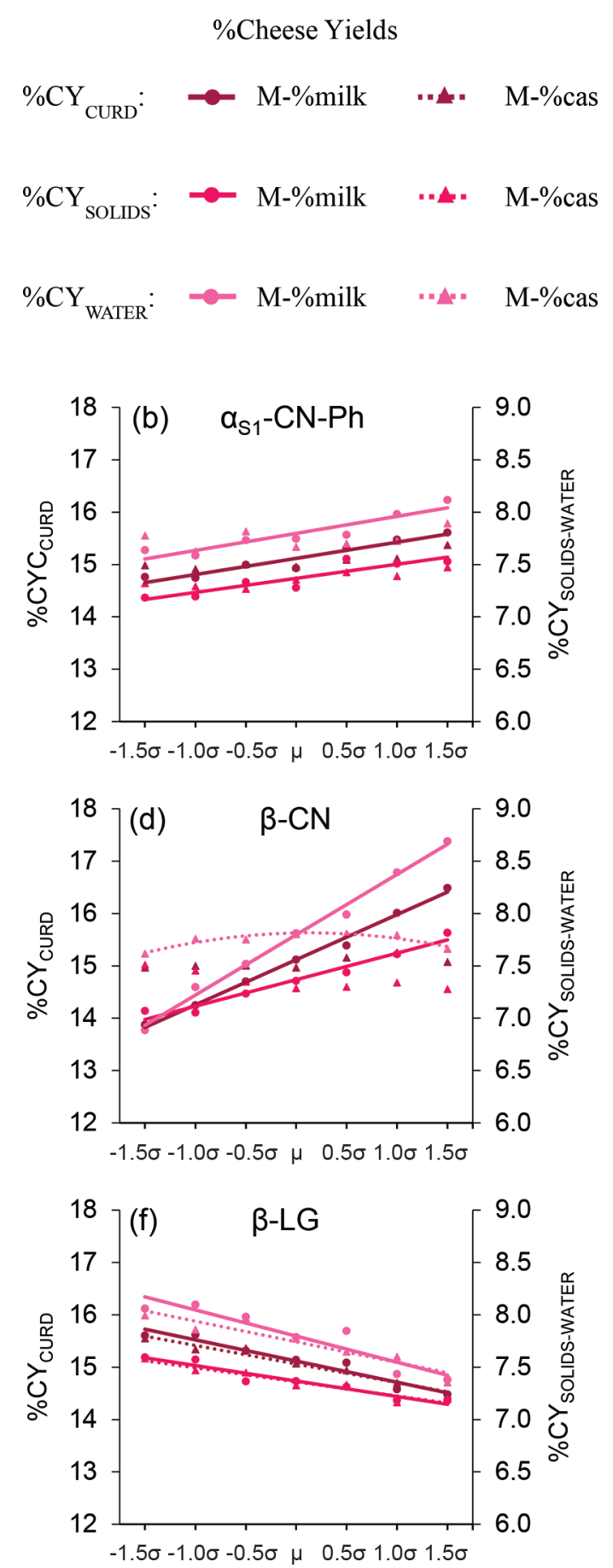

contributed to a linear increase of $0.61 \%$ in $\% \mathrm{CY}_{\text {curd }}$, $0.27 \%$ in $\% \mathrm{CY}_{\text {solids }}$, and $0.33 \%$ in $\% \mathrm{CY}_{\text {water }}$ (M-\%cas; Figure 1). Also expected was the effect of proteins on
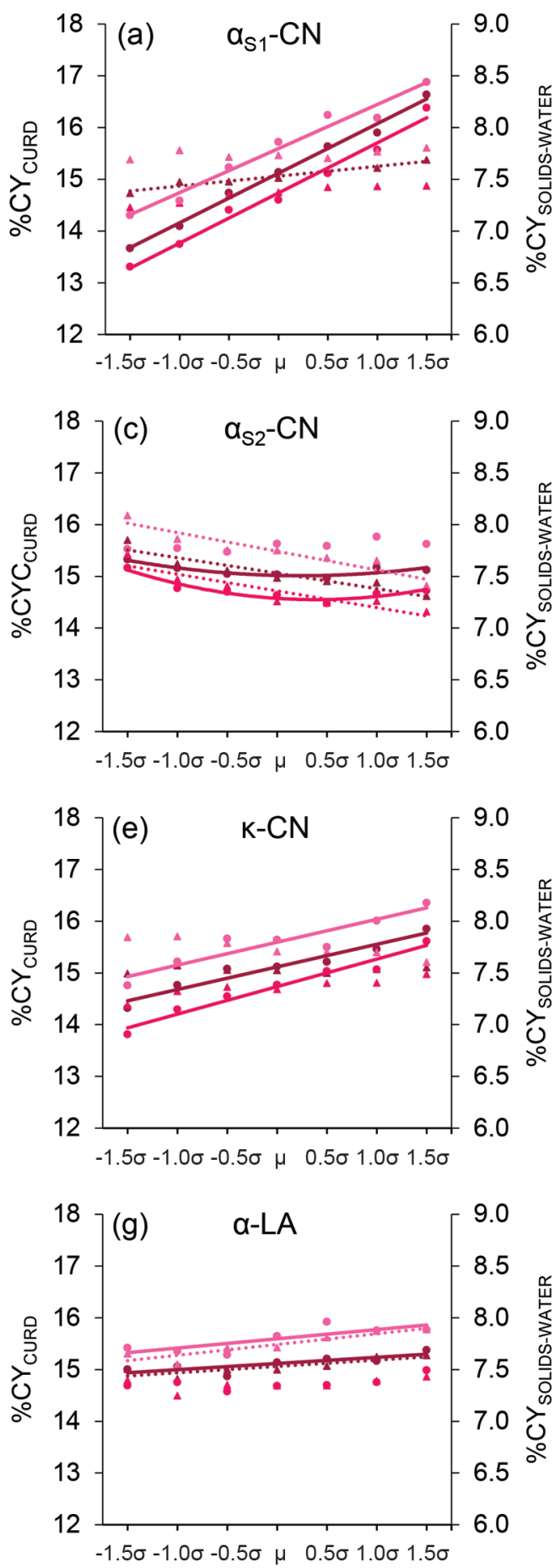

Figure 2. Effect of milk protein fractions content on cheese yields $\left(\% \mathrm{CY} ; \% \mathrm{CY}\right.$ curd, $\% \mathrm{CY}_{\text {solids }}$ and $\% \mathrm{CY}$ water $):(\mathrm{a}) \alpha_{\mathrm{S1}}-\mathrm{CN} ;(\mathrm{b}) \alpha_{\mathrm{S1}-} \mathrm{CN}-\mathrm{Ph}($ the $\alpha_{\mathrm{S} 1}-\mathrm{CN}$ fraction with 9 instead of 8 phosphorylated serine residues); (c) $\alpha_{\mathrm{S}_{2}} \mathrm{CN}$; (d) $\beta$-CN; (e) $\kappa-\mathrm{CN}$; (f) $\beta$-LG; and (g) $\alpha-\mathrm{LA}$. Results of the polynomial contrasts have been reported as the response curve (linear, quadratic, or cubic) of the variables across classes of milk proteins: solid lines represent data from the M-\%milk model, and dotted lines represent data from the M-\%cas model [proteins expressed as content in milk (M-\% milk) or as percentage of total casein content (M-\%cas)]. For each protein fraction, the class 4 represents the central class $(-0.25$ to +0.25 $\mathrm{SD}$ with respect to the mean). The amplitude of the other classes is $0.5 \mathrm{SD}$. Color version available online. 
individual $\mathrm{dCY}$, which can be considered a measure of the efficiency of cows' cheese production at the herd level. These traits are closely related to a combina- tion of daily milk production, amounts of components in milk, recoveries of milk nutrients in the curd, and $\% \mathrm{CY}$. A high content of casein in milk can make the
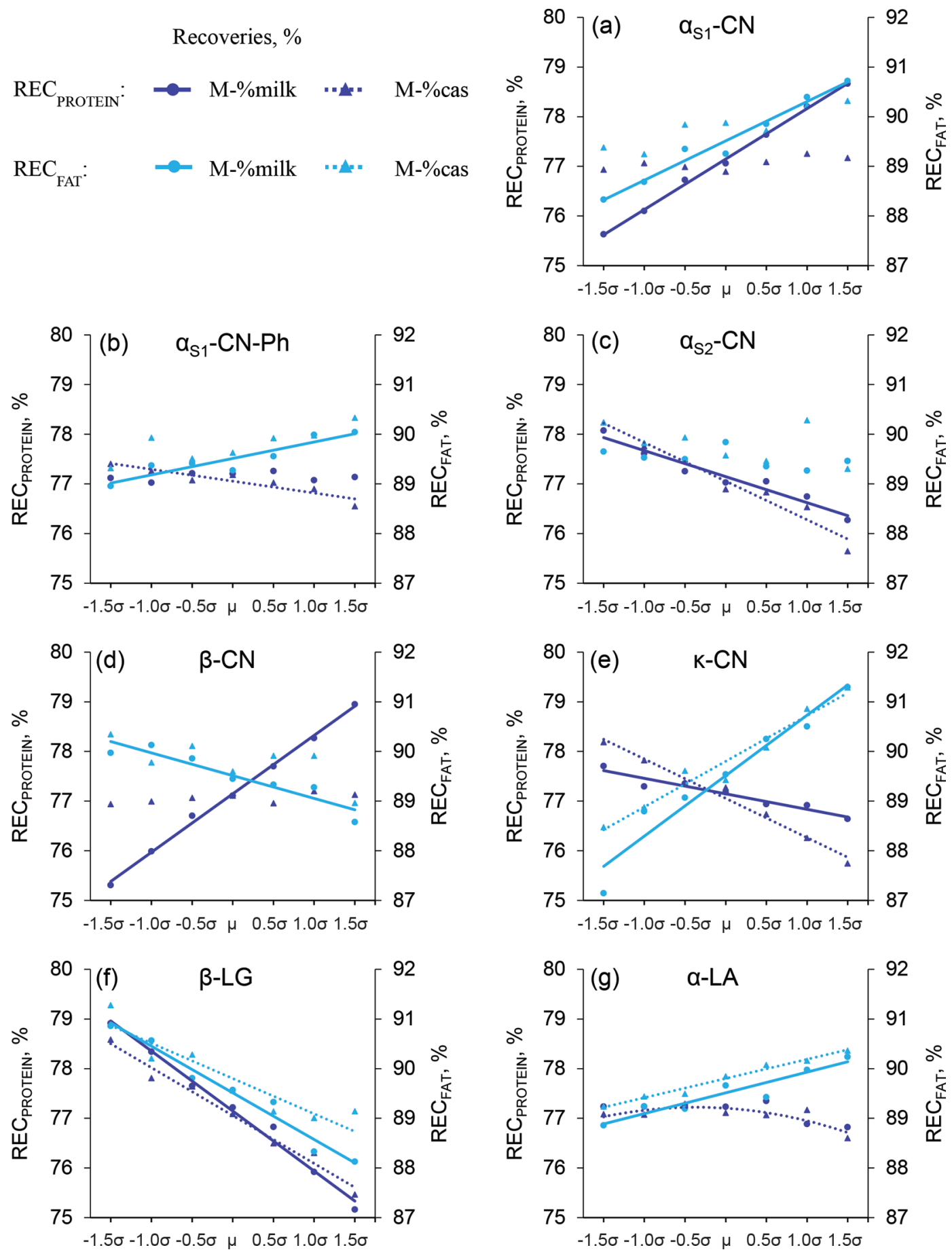

Figure 3. Effect of milk protein fractions content on milk protein and fat recovery $(\mathrm{REC})$ in the curd $\left(\mathrm{REC} \mathrm{C}_{\mathrm{protein}}\right.$ and $\left.\mathrm{REC}_{\mathrm{fat}}\right)$. (a) $\alpha_{\mathrm{S1} 1} \mathrm{CN}$; (b) $\alpha_{\mathrm{S} 1}-\mathrm{CN}-\mathrm{Ph}$ (the $\alpha_{\mathrm{S}_{1}}-\mathrm{CN}$ fraction with 9 instead of 8 phosphorylated serine residues); (c) $\alpha_{\mathrm{S}_{2}-} \mathrm{CN} ;(\mathrm{d}) \beta-\mathrm{CN} ;(\mathrm{e}) \kappa-\mathrm{CN} ;(\mathrm{f}) \beta-\mathrm{LG}$; and (g) $\alpha-\mathrm{LA}$. Results of the polynomial contrasts have been reported as the response curve (linear, quadratic, or cubic) of the variables across classes of milk proteins: solid lines represent data from the M-\%milk model, and dotted lines represent data from the M-\%cas model [proteins expressed as content in milk (M-\% milk) or as percentage of total casein content (M-\%cas)]. For each protein fraction, the class 4 represents the central class $(-0.25$ to $+0.25 \mathrm{SD}$ with respect to the mean). The amplitude of the other classes is $0.5 \mathrm{SD}$. Color version available online. 
cheese-making process highly efficient because of its effect on milk constituent recovery in the curd. For each increment of $0.1 \%$ of casein in milk, we observed an
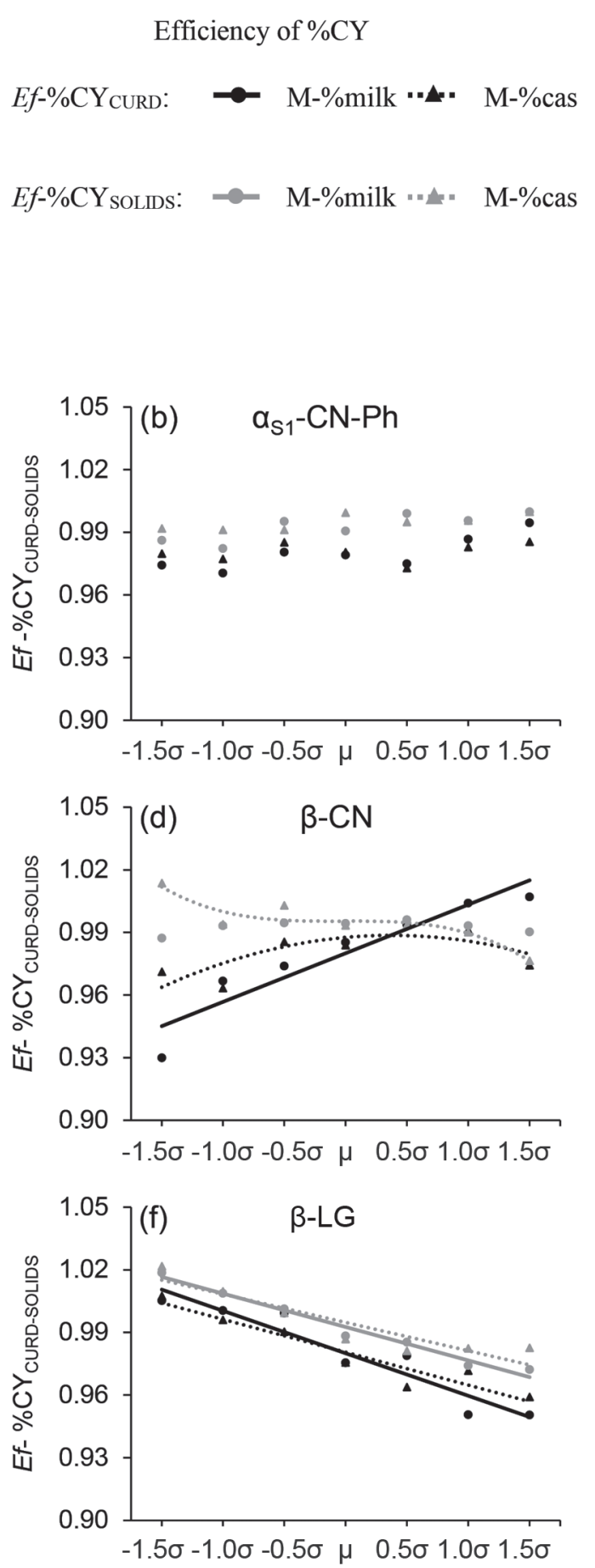

increase of $0.27 \%$ in $\mathrm{REC}_{\mathrm{fat}}$ and $0.20 \%$ in $\mathrm{REC}_{\text {protein }}$. This strong effect meant that total casein had a robust linear effect on the efficiency of \%CY, especially when
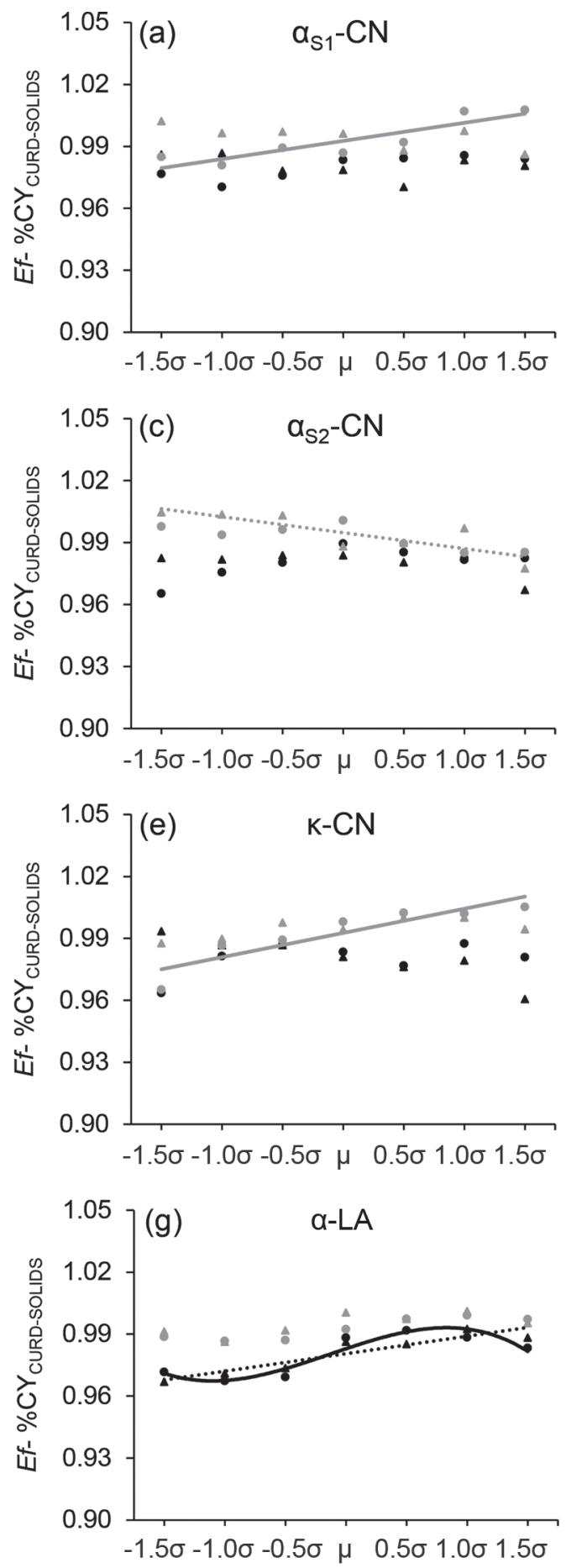

Figure 4. Effect of milk protein fractions content on efficiency of cheese yield (Ef- $\% \mathrm{CY}$; Ef- $\% \mathrm{CY}$ curd and $\mathrm{Ef}-\% \mathrm{CY}$ solids $)$. (a) $\alpha_{\mathrm{S1} 1} \mathrm{CN}$; (b)

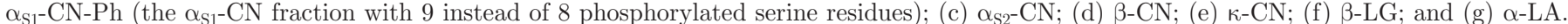
Results of the polynomial contrasts have been reported as the response curve (linear, quadratic, or cubic) of the variables across classes of milk proteins: solid lines represent data from the M-\%milk model, and dotted lines represent data from the M-\%cas model [proteins expressed as content in milk (M-\%milk) or as percentage of total casein content (M-\%cas)]. For each protein fraction, the class 4 represents the central class $(-0.25$ to $+0.25 \mathrm{SD}$ with respect to the mean). The amplitude of the other classes is $0.5 \mathrm{SD}$. 

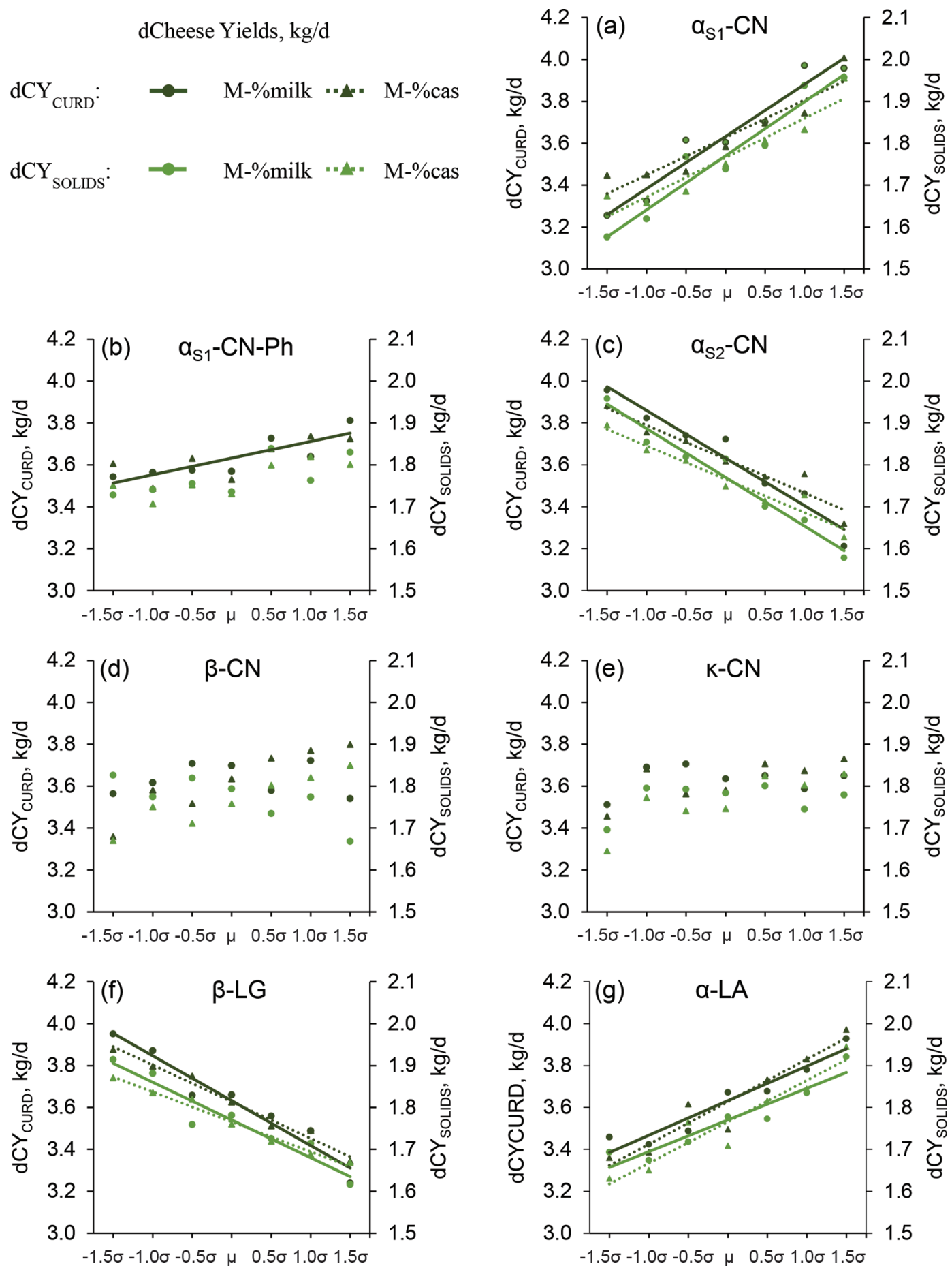

Figure 5. Effect of milk protein fractions content on daily cheese yields (dCY; dCY $\mathrm{curd}_{\text {and }} \mathrm{dCY} \mathrm{Y}_{\text {solids }}$ ). (a) $\alpha_{\mathrm{S} 1}-\mathrm{CN} ;(\mathrm{b}) \alpha_{\mathrm{S1} 1} \mathrm{CN}-\mathrm{Ph}\left(\right.$ the $\alpha_{\mathrm{S1}}-\mathrm{CN}$ fraction with 9 instead of 8 phosphorylated serine residues); (c) $\alpha_{S_{2}-} \mathrm{CN}$; (d) $\beta$-CN; (e) $\kappa$-CN; (f) $\beta$-LG; and (g) $\alpha$-LA. Results of the polynomial contrasts have been reported as the response curve (linear, quadratic, or cubic) of the variables across classes of milk proteins: solid lines represent data from the M-\%milk model, and dotted lines represent data from the M-\%cas model [proteins expressed as content in milk (M-\%milk) or as percentage of total casein content (M-\%cas)]. For each protein fraction, the class 4 represents the central class $(-0.25$ to $+0.25 \mathrm{SD}$ with respect to the mean). The amplitude of the other classes is $0.5 \mathrm{SD}$. Color version available online. 
expressed as weight of cheese $\left(\mathrm{Ef}-\% \mathrm{CY}_{\text {curd }}\right)$, due also to the greater amount of water retained in the curd.

\section{Effects of $\alpha_{s 1^{-}}$and $\alpha_{s 2^{-}}-C N$}

It is widely accepted that the concentrations and the proportions of each casein fraction play an essential role in the structure and rheological properties of the coagulum (Guinee, 2003), although less is known about the contribution of the content of each protein fraction to cheese yielding capacity and the efficiency of the cheese-making process. At the individual cow level, little attention has been paid to $\alpha_{\mathrm{S}_{1}} \mathrm{CN}$, because of low variability at its locus, and to $\alpha_{\mathrm{S}_{2}} \mathrm{CN}$, which exhibits almost monomorphic characteristics (Farrell et al., 2004).

An important function of $\alpha_{\mathrm{S}^{-}} \mathrm{CN}$ is its capacity to reduce the amounts of either $\beta$ - or $\kappa-\mathrm{CN}$, and in this regard many researchers have attributed to $\alpha_{\mathrm{S}_{1}}$-CN the role of "molecular detergent" for the other casein fractions (Farrell et al., 2006). In our data, we found that $\alpha_{\mathrm{S1}}$-CN correlated negatively only with $\beta-\mathrm{CN}(-0.63)$ when expressed as relative content in total casein, whereas no relationship was found with $\kappa_{-} \mathrm{CN}$ when expressed as relative content in total casein or as percentage in milk (data not shown).

Although $\alpha_{\mathrm{S} 1}-\mathrm{CN}$ was present in lower amounts than $\beta-\mathrm{CN}$ in our study, we observed a very positive linear effect of the percentage of $\alpha_{S_{1}}-\mathrm{CN}$ in milk, which showed the greatest increment in $\% \mathrm{CY}_{\text {curd }}$ (Figure 2a) compared with the other protein fractions (M-\%milk), which resulted from it having the highest yield of DM $\left(\% \mathrm{CY}_{\text {solids }}\right)$ and, in particular, high total milk protein recovery in the curd (Figure 3a). Our results are, in part, explained by results obtained by N. Amalfitano (University of Padova), C. Cipolat-Gotet (University of Parma), A. Cecchinato (University of Padova), M. Malacarne (University of Parma), A. Summer (University of Parma), and G. Bittante (University of Padova) (unpublished data): these authors reported greater curd firming and maximum curd firmness for milk samples with higher content of $\alpha_{\mathrm{S1}^{-}} \mathrm{CN}$ in milk. We observed that an increase in the amount of $\alpha_{\mathrm{S1}^{-}} \mathrm{CN}$ in milk had a positive effect on curd firming and syneresis, which are probably responsible for greater nutrient retention in the curd. The good efficiency of $\alpha_{\mathrm{S}_{1}} \mathrm{CN}$ and its phosphorylated form was also confirmed by the ratio between the linear regression coefficient for $\% \mathrm{CY}_{\text {curd }}$ (or $\left.\% \mathrm{CY}_{\text {solids }}\right)$ and the standard deviation of those fractions with higher values than expected (data not shown).

When compared with other caseins, the results for $\alpha_{\mathrm{S}_{2}} \mathrm{CN}$ indicate this fraction as having a small influence on the efficiency of the cheese-making process. Its relative content in total casein negatively influenced milk protein recovery in the curd, probably as a result of its negative association with maximum curd firmness (Jõudu at al., 2008; N. Amalfitano, C. Cipolat-Gotet, A. Cecchinato, M. Malacarne, A. Summer, and G. Bittante, unpublished data). Although the fluctuation in the $\alpha_{\mathrm{S}_{2}} \mathrm{CN}$ content in milk and in casein did not have a relevant influence on \%CY, we observed a more marked negative effect on dCY (Figure 5c), although its relation with daily milk production was not relevant. With respect to Ef-\%CY, the effect of $\alpha_{\mathrm{S}_{2}} \mathrm{CN}$ was comparable with that of $\alpha_{S_{1}}$ CN and presented even worse efficiency, especially for DM in the curd, with its higher proportion of total casein in milk (Figure 4c).

\section{Effect of $\beta-C N$}

More studies have been carried out on $\beta-\mathrm{CN}$ and its relationship with coagulation and curd firming processes, including its use in technological treatments to enrich the natural composition of milk (St-Gelais and Haché, 2005), than on $\alpha$-proteins. Several authors (Dunnewind et al., 1996; De Roos et al., 2000) have found a large reduction in the association between $\kappa-\mathrm{CN}$ and chymosin following addition of a small amount of $\beta-\mathrm{CN}$ to the milk solution. It seems that the role of chymosin in one or more binding sites located on para- $\kappa-\mathrm{CN}$ is shielded by $\beta-\mathrm{CN}$, or it may even be that this protein fraction is a competitor of chymosin during enzymatic coagulation of these binding sites. Okigbo et al. (1985) failed to demonstrate any relationship between the proportions of $\beta-\mathrm{CN}$ and $\kappa-\mathrm{CN}$ in total casein content and showed that inferior coagulating characteristics were associated only with a higher content of $\gamma$ - and other degraded caseins. However, these results were probably a consequence of the low number $(\mathrm{n}=9)$ of individual cows sampled. Several authors observed a reduction in curd firming time and an increase in maximum curd firmness when analyzing milk samples with a higher proportion of $\beta-\mathrm{CN}$ in total casein (Jõudu et al., 2008; N. Amalfitano, C. Cipolat-Gotet, A. Cecchinato, M. Malacarne, A. Summer, and G. Bittante, unpublished data).

With respect to cheese yield, Marziali and Ng-KwaiHang (1986) found that $\beta$-CN content in milk had a positive relationship with actual cheese yield, although it was less important than that of $\alpha-C N$. Moreover, when individual milk samples from 110 cows of Swedish Red and Swedish Holstein breeds were processed, $\beta-\mathrm{CN}$ content exhibited a strong correlation with the amount of casein retained in the curd (Hallén et al., 2010). In our study, $\% \mathrm{CY}_{\text {curd }}$ increased in relation to greater $\mathrm{REC}_{\text {protein }}$ only for $\alpha_{\mathrm{S}_{1}} \mathrm{CN}$ and $\beta-\mathrm{CN}$, whereas in the case of $\kappa$-CN the increase in $\% \mathrm{CY}$ was related more to the greater recovery of milk fat in the curd (Figure 
3e). The scenario observed for $\beta-\mathrm{CN}$ resulted in higher efficiency values for $\% \mathrm{CY}_{\text {curd }}$, although this protein induced a loss in terms of Ef- $\% \mathrm{CY}_{\text {solids }}$ when expressed as a proportion of total casein (Figure 4d). These results confirm what has been found in the processing of goats' milk (Damian et al., 2008), where a decrease in \%CY was related to an increase in $\beta-\mathrm{CN}$ as a proportion of total casein content in milk.

\section{Effect of $\mathrm{k}-\mathrm{CN}$}

In enzymatic coagulation, $\kappa-\mathrm{CN}$ is hydrolyzed to produce para- $\kappa-\mathrm{CN}$ ( $\kappa-\mathrm{CN}$ fragment: $1-105)$, which is linked to the micelle core, and macropeptides $(\kappa-\mathrm{CN}$ fragment: $106 \pm 169$ ), which constitute about $30 \%$ k-CN and represent 4 to $5 \%$ of milk total casein. During the coagulation process, when about $85 \%$ of the total $\mathrm{k}$-CN is hydrolyzed, micelles lose their colloidal stability and begin to aggregate progressively into a gel network (Guinee, 2003).

Given the high importance of $\kappa$-CN function in the coagulation process, the genetics of its variants have also been widely investigated. The superiority of the B variant with regard to coagulation time and the curd firming process is well known (Bittante et al., 2012). However, Bonfatti et al. (2011a) discovered that this superiority is due to the high $\kappa$-CN content in milk (and relative proportion in casein) when this variant is present and found that when the statistical model included the effect of the content of this protein fraction, the coagulation properties were not affected by its genetic variants. Moreover, Bonfatti et al. (2011a) found that $\% \mathrm{CY}_{\text {curd }}$ in field conditions is not affected by genetic variants when milk samples with similar total CN composition are processed. Verdier-Metz et al. (2001) reported greater \% CY in milks presenting high frequencies of the $\kappa-\mathrm{CN} \mathrm{B}$ variant with higher casein: protein ratios in the production of Saint Nectaire. However, milk with a high $\kappa-\mathrm{CN}$ content has small casein micelles, which form rennet curd with improved rheological properties and a high capacity to entrap milk constituents (especially fat droplets) into the paracasein matrix (Niki et al., 1994; Walsh et al., 1998). Using a laboratory cheese-making procedure to process individual milk samples, Macheboeuf et al. (1993) also observed a positive effect of $\mathrm{\kappa}$-CN content in milk on $\% \mathrm{CY}_{\text {water }}$, although water retention in the curd could have been influenced by the use of a centrifuge for whey expulsion (Cipolat-Gotet et al., 2016). Our study confirms the positive linear effect of $\kappa-\mathrm{CN}$ on all $\% \mathrm{CY}$ traits when expressed as percentage of milk, albeit less important than the effects of $\alpha \mathrm{s}_{1}-\mathrm{CN}$ and $\beta-\mathrm{CN}$, and subsequently a weaker effect on this protein's cheese yield efficiency, in particular for $\mathrm{Ef}-\% \mathrm{CY}_{\text {curd }}$ (Figure 4e; M-\%milk and M-\%cas). This was probably due to the higher losses of whey proteins resulting from the negative effect of $\kappa-\mathrm{CN}, \mathrm{REC}_{\text {protein }}$, and syneresis (N. Amalfitano, C. Cipolat-Gotet, A. Cecchinato, M. Malacarne, A. Summer, and G. Bittante, unpublished data), especially when there is a greater proportion of $\kappa-\mathrm{CN}$ in the casein. Moreover, in enzymatic coagulation, the higher content of $\kappa-\mathrm{CN}$ in milk can increase the amount of glycomacropeptide (fragments 106-169) lost in the whey as a consequence of $\kappa$ - $\mathrm{CN}$ hydrolysis by chymosin. The positive effect of $\kappa-\mathrm{CN}$ on the recovery of milk components (Donnelly et al., 1984; Dalgleish et al., 1989) in the casein matrix was mostly related to fat whether this protein was expressed as a percentage of milk or of total casein content (Figure 3e). These results agree with Malacarne et al.'s (2006) study of milk samples from Italian Brown cows in the production of Parmigiano Reggiano.

\section{Effect of Whey Proteins}

In the present study, we analyzed the 2 main whey proteins in bovine milk, $\beta$-LG and $\alpha$-LA, both of mammary derivation, that contribute approximately $50 \%$ and $20 \%$ to total whey proteins, respectively. Although they are not directly involved in the enzymatic coagulation process, whey proteins are dissolved in the cheese moisture (about $4 \%$ in total) and contribute very little to $\% \mathrm{CY}_{\text {curd }}$. Through the use of milk treatments, such as concentration by ultrafiltration, whey proteins can be incorporated into the curd, making the cheese-producing process more efficient in terms of $\mathrm{REC}_{\text {protein }}$ and $\% \mathrm{CY}_{\text {curd }}$. Moreover, as these proteins precipitate under intense heating or salting, an increase in $\mathrm{REC}_{\text {protein }}$ can also be observed when whey proteins are subjected to heat treatment, such as in the case of ricotta (Guinee, 2003).

The finding that whey protein had little influence in the gelation phase (N. Amalfitano, C. Cipolat-Gotet, A. Cecchinato, M. Malacarne, A. Summer, and G. Bittante, unpublished data) compared with caseins, for which we found a relation between coagulation and efficiency of the cheese-making processes, was not in line with our results for \%CY, REC, and Ef-\%CY traits, especially in the case of $\alpha$-LA. Whey proteins are not involved directly in the renneting process, but they greatly influence recovery in the curd, as a part of these fractions ends up in the curd (as part of the whey retained in the curd) and the whey. We observed that $\beta$-LG had a highly negative influence on the cheesemaking process, especially with regard to fat and protein recoveries (Figure 3f), where it exhibited a worse pattern than the other protein fractions. As a consequence of the strong relationship between recoveries in 
the curd and cheese-making efficiency, this fraction was the least efficient protein in terms of \%CY (Figure 4f). In contrast, $\alpha$-LA had a fairly positive effect on the recovery of fat in the curd when it increased as percentage of casein. The increase in $\alpha$-LA compared with the other fractions may be considered positive in terms of Ef- $\% \mathrm{CY}_{\text {curd }}$ (Figure $4 \mathrm{~g}$ ), and it had a positive effect on daily cheese production. In contrast, $\beta-\mathrm{LG}$, together with $\alpha_{\mathrm{S}_{2}} \mathrm{CN}$, were the only fractions that negatively influenced daily cheese production at the individual level cow. Dadousis et al. (2018) reported a positive genetic correlation between $\alpha-\mathrm{LA}$ and $\mathrm{dMY}$, and the highest value of dMY variance explained by this fraction compared with the other proteins. Through the use of 2-dimensional electrophoresis, Hsieh and Pan (2012) observed that a fraction of $\beta-\mathrm{LG}$ was found in the curd together with $\alpha_{\mathrm{S}^{-}}, \alpha_{\mathrm{S}^{-}}, \beta-$, and $\kappa$-CN after incubation of milk with chymosin. In contrast to our results, Hallén et al. (2010) observed that milk nutrient losses in the curd after a simulated pressing were positively associated with $\alpha$-LA content in milk, but, as mentioned before, the use of a centrifuge to separate the curd from the whey could influence the results in terms of milk nutrient recoveries and Ef-\%CY traits.

\section{CONCLUSIONS}

We report a highly significant effect of protein fractions on the efficiency of the cheese-making process. This study permitted us to assess the effect of each single protein fraction quantity in milk and its proportion to total casein on the cheese-making process. The quantities and interactions of protein fractions appear to be important in milk-to-cheese processes, where the effects of the amounts of proteins in the milk were more significant. Among the different proteins in the milk, Ef- $\% \mathrm{CY}_{\text {curd }}$ was positively associated mostly with $\beta-\mathrm{CN}$, due in particular to greater water retention, whereas the amounts of $\alpha_{\mathrm{S}_{1}}-\mathrm{CN}$ and $\kappa$-CN influenced the efficiency of DM yield as a consequence of their relationship with the recovery rates of protein and fat in the curd. In contrast, $\beta-\mathrm{LG}$ was highly negatively related to all the traits associated with the cheese-making process. In terms of daily cheese yield, whey proteins were also of high importance as they exhibited positive relationships with $\alpha$-LA and negative relationships with $\beta$-LG. Although the characteristics of coagulation and the curd firming process can influence the relationships between milk protein (and its fractions) and cheesemaking efficiency, it was very important to carry out a study using a laboratory cheese-making procedure to process individual milk samples so that information could be collected for use in detailed monitoring of milk quality at the herd level, breeding selection programs (also linking details of the proteins' genetic variants), and designing appropriate milk payment systems. Given that HPLC analyses to assess protein fractions are expensive, complex, and time consuming, it would be useful from a practical point of view to find faster, easier-to-use, and less costly alternative methods (e.g., infrared spectroscopy). Assessment of the effectiveness of infrared technology and the predictive ability of calibration equations for milk protein fractions as well as the study of the genetic and genomic variations in Fourier-transform infrared-based predictions at the population level remain matters for further studies.

\section{ACKNOWLEDGMENTS}

The authors acknowledge Valentina Bonfatti and Paolo Carnier (Department of Comparative Biomedicine and Food Science, University of Padova) for their cooperation in assessing the milk protein fractions.

\section{REFERENCES}

Ali, A. K. A., and G. E. Shook. 1980. An optimum transformation for somatic cell concentration in milk. J. Dairy Sci. 63:487-490.

Banks, J. M. 2007. Cheese yield. Pages 100-114 in Cheese Problems Solved. P. L. H. McSweeney, ed. Woodhead, Cambridge, UK.

Bittante, G., C. Cipolat-Gotet, F. Malchiodi, E. Sturaro, F. Tagliapietra, S. Schiavon, and A. Cecchinato. 2015. Effect of dairy farming system, herd, season, parity, and days in milk on modeling of the coagulation, curd firming, and syneresis of bovine milk. J. Dairy Sci. 98:2759-2774.

Bittante, G., M. Penasa, and A. Cecchinato. 2012. Invited review: Genetics and modeling of milk coagulation properties. J. Dairy Sci. 95:6843-6870.

Bobe, G., D. C. Beitz, A. E. Freeman, and G. L. Lindberg. 1998. Separation and quantification of bovine milk proteins by reversed-phase high-performance liquid chromatography. J. Agric. Food Chem. 46:458-463.

Bonfatti, V., A. Cecchinato, G. Di Martino, M. De Marchi, L. Gallo, and P. Carnier. 2011a. Effect of $\kappa$-casein B relative content in bulk milk $\kappa$-casein on Montasio, Asiago, and Caciotta cheese yield using milk of similar protein composition. J. Dairy Sci. 94:602-613.

Bonfatti, V., A. Cecchinato, L. Gallo, A. Blasco, and P. Carnier. 2011 b. Genetic analysis of detailed milk protein composition and coagulation properties in Simmental cattle. J. Dairy Sci. 94:5183-5193.

Bonfatti, V., L. Grigoletto, A. Cecchinato, L. Gallo, and P. Carnier. 2008. Validation of a new reversed-phase high-performance liquid chromatography method for separation and quantification of bovine milk protein genetic variants. J. Chromatogr. 1195:101-106.

Caroli, A. M., S. Chessa, and G. J. Erhardt. 2009. Invited review: Milk protein polymorphisms in cattle: Effect on animal breeding and human nutrition. J. Dairy Sci. 92:5335-5352.

Cipolat-Gotet, C., A. Cecchinato, G. Stocco, and G. Bittante. 2016. 9-MilCA as a rapid, partly-automated method for simultaneously recording of milk coagulation, curd firming, syneresis, cheese yield, and curd nutrients recovery/whey loss. J. Dairy Sci. 99:1065-1082.

Dadousis, C., C. Cipolat-Gotet, G. Bittante, and A. Cecchinato. 2018. Inferring genetic parameters on latent variables underlying milk yield and quality, protein composition, curd firmness and cheesemaking traits in dairy cattle. Animal 12:224-231.

Dalgleish, D. G., D. S. Horne, and A. J. R. Law. 1989. Size-related differences in bovine casein micelles. Biochim. Biophys. Acta 991:383-387. 
Damian, J. P., I. Sacchi, S. Reginensi, D. De Lima, and J. Bermudez. 2008. Cheese yield casein fraction and major components of milk of Saanen and Anglo-Nuubian dairy goats. Arguivo Brasilero de Medicina Veterinaria de Zootecnia 60:1564-1569.

De Roos, A. L., R. J. Geurts, and P. Walstra. 2000. The association of chymosin with artificial casein micelles. Int. Dairy J. 10:225-232.

Donnelly, W. J., G. P. McNeill, W. Buchheim, and T. C. A. McGann. 1984. A comprehensive study of the relationship between size and protein-composition in natural bovine casein micelles. Biochim. Biophys. Acta 789:136-143.

Dunnewind, B., A. L. De Roos, and T. J. Geurts. 1996. Association of chymosin with caseins in solution. Netherlands Milk Dairy J. 50:121-133.

Emmons, D. B., C. Dubé, and H. W. Modler. 2003. Transfer of protein from milk to cheese. J. Dairy Sci. 86:469-485.

Emmons, D. B., C. A. Ernstrom, C. Lacroix, and P. Verret. 1990 Predictive formulas for yield of cheese from composition of milk: A review. J. Dairy Sci. 73:1365-1394.

Farrell, H. M., R. Jimenez-Flores, G. T. Bleck, E. M. Brown, J. E. Butler, L. K. Creamer, C. L. Hicks, C. M. Hollar, K. F. Ng-KwaiHang, and H. E. Swaisgood. 2004. Nomenclature of the proteins of cows' milk-Sixth revision. J. Dairy Sci. 87:1641-1674.

Farrell, H. M., E. L. Malin, E. M. Brown, and P. X. Qi. 2006. Casein micelle structure: What can be learned from milk synthesis and structural biology? Curr. Opin. Colloid Interface Sci. 11:135-147.

Guinee, T. P. 2003. Role of protein in cheese and cheese products. Pages 1,083-1,159 in Advanced Dairy Chemistry. Vol. 1B: Proteins: Basic Aspects. 3rd ed. P. F. Fox and P. L. H. McSweeney, ed. Springer, New York, NY.

Guinee, T. P., P. D. Pudja, W. J. Reville, D. Hanington, E. Mulholland, M. Cotter, and T. M. Cogan. 1995. Composition, microstructure and maturation of semi-hard cheeses from high protein ultrafiltered milk retentates with different levels of denatured protein. Int. Dairy J. 5:543-568.

Hallén, E., T. Allmere, J. Näslund, A. Andrén, and A. Lundén. 2007. Effect of genetic polymorphism of milk proteins on rheology of chymosin-induced milk gels. Int. Dairy J. 17:791-799.

Hallén, E., A. Lundén, T. Allmere, and A. Andrén. 2010. Casein retention in curd and loss of casein into whey at chymosin-induced coagulation of milk. J. Dairy Res. 77:71-76.

Hsieh, J. F., and P. H. Pan. 2012. Proteomic profiling of the coagulation of milk proteins induced by chymosin. J. Agric. Food Chem. 60:2039-2045.

ISO (International Organization for Standardization). 2002. Dried milk, dried ice-mixes and processed cheese - Determination of lactose content-Part 1: Enzymatic method utilizing the galactose moiety of the lactose (ISO 5765-1/IDF 79-1). ISO, Geneva, Switzerland.

ISO (International Organization for Standardization). 2004. MilkDetermination of casein-nitrogen content-Part 1: Indirect method (ISO 17997-1/IDF 29). ISO, Geneva, Switzerland.

ISO (International Organization for Standardization). 2010a. Milk, cream and evaporated milk-Determination of total solids content (ISO 6731:2010/IDF 21). ISO, Geneva, Switzerland.
ISO (International Organization for Standardization). 2010b. MilkDetermination of fat content-Gravimetric method (ISO 1211/ IDF 1). ISO, Geneva, Switzerland.

ISO (International Organization for Standardization). 2014. Milk and milk products - Determination of nitrogen content-Part 1: Kjeldahl principle and crude protein calculation (ISO 8968-1/IDF 201). ISO, Geneva, Switzerland.

Jõudu, I., M. Henno, T. Kaart, T. Püssa, and O. Kärt. 2008. The effect of milk protein contents on the rennet coagulation properties of milk from individual dairy cows. Int. Dairy J. 18:964-967.

Macheboeuf, D., J. B. Coulon, and P. D'Hour. 1993. Effect of breed, protein genetic variants and feeding on cows' milk coagulation properties. J. Dairy Res. 60:43-54.

Malacarne, M., A. Summer, E. Fossa, P. Formaggioni, P. Franceschi, M. Pecorari, and P. Mariani. 2006. Composition, coagulation properties and Parmigiano-Reggiano cheese yield of Italian Brown and Italian Friesian herd milks. J. Dairy Res. 73:171-177.

Marziali, A. S., and K. F. Ng-Kwai-Hang. 1986. Effects of milk composition and genetic polymorphism on coagulation properties of milk. J. Dairy Sci. 69:1793-1798.

Niki, R., K. Royama, Y. Sano, and K. Nishinari. 1994. Rheological study on the rennet-induced gelation of casein micelles with different size. Polym. Gels Netw. 2:105-118.

NRC. 2001. Nutrient Requirements of Dairy Cattle. 7th rev. ed. Natl. Acad. Press, Washington, DC.

Okigbo, L. M., G. H. Richardson, R. J. Brown, and C. A. Ernstrom 1985. Casein composition of cow's milk of different chymosin coagulation properties. J. Dairy Sci. 68:1887-1892.

Rybak, O. 2014. The role of milk proteins in the structure formation of dairy products. Ukr. Food J. 3:350-360.

St-Gelais, D., and S. Haché. 2005. Effect of $\beta$-casein concentration in cheese milk on rennet coagulation properties, cheese composition and cheese ripening. Food Res. Int. 38:523-531.

Stocco, G., C. Cipolat-Gotet, V. Gasparotto, A. Cecchinato, and G. Bittante. 2018. Breed of cow and herd productivity affect milk nutrient recovery in curd, and cheese yield, efficiency and daily production. Animal 12:434-444.

Van Slyke, L. L., and W. V. Price. 1949. Cheese. Orange Judd, New York, NY

Verdier-Metz, I., J. B. Coulon, and P. Pradel. 2001. Relationship between milk fat and protein contents and cheese yield. Anim. Res. 50:365-371.

Walsh, C. D.. T. P. Guinee, W. D. Reville, D. Harrington, J. J. Murphy, B. T. O'Kennedy, and R. J. FitzGerald. 1998. Influence of kappa-casein genetic variant on rennet gel microstructure, cheddar cheesemaking properties and casein micelle size. Int. Dairy J. 8:707-714.

Wedholm, A., L. B. Larsen, H. Lindmark-Månsson, A. H. Karlsson, and A. Andrén. 2006. Effect of protein composition on the cheesemaking properties of milk from individual dairy cows. J. Dairy Sci. 89:3296-3305. 